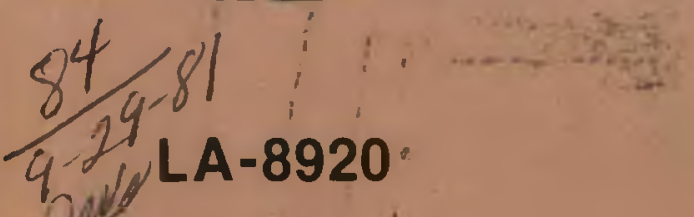

(1) 31380

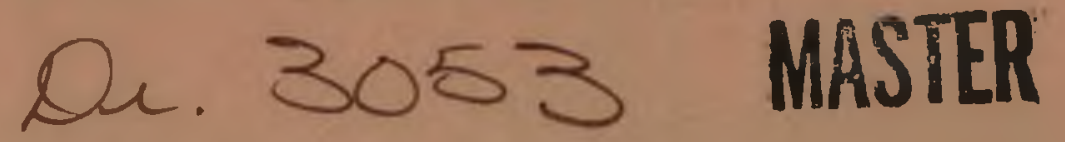

\title{
Prediction of Crystal Densities of Organic Explosives by Group Additivity
}

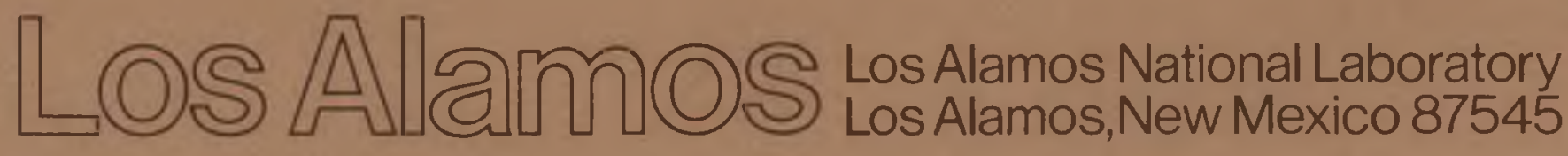


This work was supported by the US Department of Energy and the Naval Surface Weapons Center under project order number N60921-80-WR-W0165.

Edited by Katherine H. Harper

Photocomposition by Alice Creek

\section{DISCLALMER}

This report was prepared as an account of work sponsored by an agency of the United States Covernment. Netther the United States Government nor any agency thereof, nor any of their employees, makes any warranty, express or implied, or assumes any legal liability or responsibility for the accuracy, completeness, or usefulness of any information, apparatus, product, or process disclosed, or represents that its use would not infringe privately owned rights. References herein to any specific commercial product, process, or service by trade name, trademark, manufacturer, or otherwise, does not necessarily constitute or imply its endorsement, recommendation, or favoring by the United States Government or any agency thereof. The views and opinions of authors expressed herein do not necessarily state or reflect those of the United States Government or any agency thereof. 


\section{DISCLAIMER}

This report was prepared as an account of work sponsored by an agency of the United States Government. Neither the United States Government nor any agency Thereof, nor any of their employees, makes any warranty, express or implied, or assumes any legal liability or responsibility for the accuracy, completeness, or usefulness of any information, apparatus, product, or process disclosed, or represents that its use would not infringe privately owned rights. Reference herein to any specific commercial product, process, or service by trade name, trademark, manufacturer, or otherwise does not necessarily constitute or imply its endorsement, recommendation, or favoring by the United States Government or any agency thereof. The views and opinions of authors expressed herein do not necessarily state or reflect those of the United States Government or any agency thereof. 


\section{DISCLAIMER}

Portions of this document may be illegible in electronic image products. Images are produced from the best available original document. 


\section{Prediction of Crystal Densities of Organic Explosives by Group Additivity}

James R. Stine 
? 


\title{
PREDICTION OF CRYSTAL DENSITIES OF ORGANIC EXPLOSIVES BY GROUP ADDITIVITY
}

\author{
by
}

James R. Stine

\begin{abstract}
The molar volume of a crystalline organic compound is assumed to be a linear combination of its constituent volumes. Compounds consisting only of the elements hydrogen, carbon, nitrogen, oxygen, and fluorine are considered. The constituent volumes are taken to be the volumes of atoms in particular bonding environments and are evaluated from a large set of crystallographic data. The predicted density has an expected error of about $3 \%$. These results are applied to a large number of explosives compounds.
\end{abstract}

\section{INTRODUCTION}

Of particular importance in designing new explosives is the ability to predict a compound's performance before the laborious and expensive task of synthesizing it is undertaken. One property of the compound that is helpful in evaluating an explosive's performance is its density. For example, we know from experiments that the detonation velocity of one-component explosives increases with increasing density. ${ }^{1.2}$ In fact, for most explosives, detonation velocity is a linear function for densities greater than unity. Also, the $\mathrm{C}-\mathrm{J}$ pressure (Chapman-Jouget - the pressure behind the shock front) can be shown to vary as the square of the density when the density is in the range $1.0-1.6 \mathrm{~g} / \mathrm{cm}^{3}$.

Kamlet and Jacobs ${ }^{3}$ showed that simple relations for the detonation velocity and $\mathrm{C}-\mathrm{J}$ pressure can be used to fit numerical data resulting from a complex computer code. These simple relations, which are valid for $\mathrm{C}-\mathrm{H}-\mathrm{N}$ $\mathrm{O}$ exposives, depend on moles of detonation gases per unit weight of explosive, average molecular weight of these gases, chemical energy of the detonation reaction. and density. They assume the detonation products can be deduced from the compound's composition and oxygen balance. Thus, relations for the detonation velocity and $\mathrm{C}-\mathrm{J}$ pressure depend only on the elemental composition, density, and the heat of formation of the explosive. As shown in later papers, ${ }^{4-7}$ these formulas predict values that are in agreement with measured detonation velocities and $\mathrm{C}-\mathrm{J}$ pressures to within experimental accuracy. Benson and $\mathrm{Buss}^{8}$ showed that thermodynamic properties are additive and that the heat of formation can be estimated to about $\pm 3 \mathrm{kcal} / \mathrm{mole}$.

Rothstein and Petersen ${ }^{9}$ also developed a simple empirical relation for detonation velocity, and the results for 64 explosives agreed with experimental values to about $\pm 2.3 \%$.

Aizenshtadt ${ }^{10}$ also developed an empirical set of simple formulas for calculating detonation velocity. These formulas have as parameters the chemical formula, the standard enthalpy of formation, and the density of the explosive. They apparently are valid over the density range $1.30-1.90 \mathrm{~g} / \mathrm{cm}^{3}$ although no error limits have been established.

Several methods exist to estimate the density of a compound and can be divided roughly into two broad categories: those of a theoretical nature and those of an empirical nature. The theoretical approach uses detailed information about the crystal structure in calculating density of a compound. That is, the density of an organic compound can be calculated on a fundamental basis if all inter- and intramolecular forces are known. ${ }^{11-14}$ This 
method has the dual advantage that structures for different polymorphs can be calculated and unique bonding situations, such as hydrogen bonding or conjugation, can be handled. On the other hand, the interand intramolecular forces for these large organic compounds are not well characterized and their calculations are extremely complex. However, this method is being pursued by the author and will be described in a future report.

Alternatively, the density of a compound can be estimated by taking an empirical approach. The molar volume of a compound usually is assumed to be a linear combination of the volumes of its constitutents, whose values are determined empirically. The volume of a molecule may correspond to the volumes of its constituent chemical entities, such as $-\mathrm{NO}_{2},-\mathrm{OH},-\mathrm{NH}_{2}$, or of its atoms. Of course, the molar volume is only approximately additive and is complicated by steric effects, conjugation, and ring systems, to mention only a few. On the other hand, the great mass of experimental crystallographic data suggests that atoms in similar bonding situations have similar bond lengths and hence would occupy similar volumes.

This empirical method is the concern in this report, which describes a simple method of predicting the molar volume of a crystalline organic compound, along with sufficient error analysis to set confidence limits on the predicted density.

The next section briefly describes previous empirical methods; Sec. III discusses the technique developed here; and Sec. IV presents the results. Section V contains a list of possible and existing explosives along with their calculated densities.

\section{BACKGROUND}

The empirical method of estimating molar volumes by additive constituent volumes has long been recognized as being simple and relatively accurate. Investigations and properties relating to molar volumes date back to the first half of the nineteenth century for both liquids ${ }^{15}$ and solids. ${ }^{16}$ Much of the liquid work was concerned with organic compounds - the solid work with inorganic. In both cases investigators were usually concerned with additive volumes for systems of compounds that form a homologous series (alkanes, for example).

Although different investigators were concerned with different homologous series and hence arrived at different constituent volumes, and their results were based on limited empirical data, some basic conclusions were reached and form the basis of the method. For example, they found that isomeric compounds have approximately the same molar volumes, and that the molar volume is approximately a linear function of the addition of a specific chemical group.

Exner $^{17}$ was one of the first to consolidate the ideas of the additivity of constituent volumes and to be concerned with the statistics related to his calculated values. Also, he suggested that other additive physical properties, such as parachor, ${ }^{18}$ are additive only because the molecular weight or molar volume is approximately additive, and hence the molar volume is fundamentally the more important property to consider.

In Exner's approach, $1 / \rho$ (where $\rho$ is density) is plotted vs $1 / M$ (where $M$ is molecular weight) for a homologous series. From the slope and intercept of the resulting straight line, he deduced values for the constituent volumes in the homologous series. When values for these volumes are known, a different homologous series can be selected and values for other constituent volumes can be deduced, and so forth, until values for all constituent volumes of interest have been calculated.

Nielsen ${ }^{19}$ extended Exner's method to include constituent volumes related to multimembered ring systems and chemical entities found in explosives compounds. $\mathrm{He}$ found that 10 to 18 -member ring systems make a negative contribution to the molar volume, whereas all other ring systems make a positive contribution. However, he indicated neither the number of compounds on which these data were based nor the error associated with each of the constituent volumes. The actual error in his predicted densities seems to be larger than the reported error of $<5 \%$.

Tarver et al. ${ }^{20-21}$ defined a different set of constituent volumes from those of Exner or Nielsen and reported that his calculated densities agreed with the observed densities, within about $1.5 \%$. Although values for 5 of their constituent volumes were based on 25 compounds, values for the remaining 73 constituent volumes were based on only 148 compounds and hence their reported error probably is also too small. Neither Nielsen nor Tarver et al. differentiated between liquids and solids in the compounds that made up their basis sets.

Immirizi and Perini ${ }^{22}$ defined a set of 15 constituent volumes that are basically atomic volumes, although ring contributions were also included. Their data base consisted of 500 organic crystalline compounds in which the ring systems were restricted to benzene and napthalene derivatives. Because of the large basis set and the small 
number of constituent volumes, their estimated error of $2-3 \%$ ( $4 \%$ if all types of rings are included) in a predicted density is perhaps more valid than those reported by previous investigators. They also included density calculations for compounds not in their basis set so that realistic estimates of the method's predictive ability could be assessed.

A method developed by Cichra et al. ${ }^{23}$ is similar to that just described, although their basis set was restricted to explosives and explosives-related compounds.

All of these empirical methods are concerned with estimating a compound's molar volume $\left(\mathrm{cm}^{3} /\right.$ mole) or equivalently its crystal volume ( $\AA^{3} /$ molecule). The constituent volumes then include contributions from the actual volume occupied by the molecule (molecular volume) and the void between the molecules. Alternatively, the molecular volume and packing fraction (ratio of molecular to crystal volume) can be estimated separately. Kitaigorodsky ${ }^{24}$ estimated the molecular volume by assuming that the volume of each atom was defined by an empirically determined van der Waals radius. For such a calculation the detailed geometry of the molecule must be known so that the volume common to a group of atoms is not included more than once. Kitaigorodsky derived a simple formula for calculating the volume common to two adjacent atoms. Higher order contacts between atoms may, for the most part, be neglected. Including these corrections requires a computer code and hence the method loses some of its attractiveness. Based on experimental crystal volumes, he observed that most packing fractions lie in the range 0.65-0.77.

$\mathrm{Cady}^{25}$ used Kitaigorodsky's method, with van der Waals radii taken from Bondi, ${ }^{26}$ to calculate the molecular volumes for a variety of explosives. From these data and observed densities he then calculated the packing fractions for these compounds and found that they ranged from $0.63-0.85$. This conclusion was based on an argument that hydrogen atoms bonded to carbon atoms cannot form hydrogen bonds. He also found the packing fraction to be roughly linear, with a variable representing the ratio of number of hydrogen atoms bonded to carbon atoms to total number of atoms in the molecule.

The method described in the next section differs from the previous methods in that it is based on a much larger set of empirical data and hence the confidence limits may be determined more accurately. The method is also more easily applied to a wide variety of compounds than are the previous methods, and the constituent volumes have simple intuitive meanings.

\section{METHOD}

The molar volume, $\mathrm{V}$, is assumed to be a linear combination of the constituent volumes, $v_{\mathrm{i}}$. That is, for the $j$-th compound,

$v_{j}=\sum_{i=1}^{n} a_{i j} v_{1}$

or in matrix notation,

$\mathrm{V}=\mathrm{Av}+\varepsilon$

where $A$ is the coefficient matrix (and $a_{i j}$ are its elements). The vector of the deviations between the observed and calculated molar volumes, $\varepsilon$, is needed to make the equations consistent. I assumed that there are $m$ compounds in the basis set and $n$ constituent volumes. Thus $V$ and $\varepsilon$ are vectors of length $m, v$ is a vector of length $n$, and $A$ is a matrix of dimension $m \times n$.

Equation (2) is solved in the least-squares sense. ${ }^{27}$ That is, the magnitude of $\varepsilon$ squared is minimized with respect to the constituent volumes. This linear leastsquares estimator of $v, \hat{v}$, is given by

$\hat{\mathrm{V}}=\left(\mathrm{A}^{\mathrm{T}} \mathrm{A}\right)^{-1} \mathrm{~A}^{\mathrm{T}} \mathrm{V}$

where $A^{T}$ denotes the transpose of $A$.

One advantage of the linear least-squares method is that a unique solution to Eq. (2) always exists, provided that the normal matrix, $A^{T} A$, is not singular (that is, its determinant is not zero). The normal matrix is a square matrix of dimension $n \times n$, where $n$ is usually small (here $<50$ ). Techniques exist to calculate the normal matrix without having the coefficient matrix, $A$, in the computer's memory. When $\mathrm{m}$ is large, as is the case here, a considerable savings of the computer's available memory results.

More importantly, the linear least-squares method allows one to easily estimate the errors in $\mathrm{v}$ and in the 
calculated molar volume. That is, an unbiased estimator of the true variance, $\sigma^{2}$, is given by

$\mathrm{s}^{2}=\varepsilon^{\mathrm{T}} \varepsilon /(\mathrm{m}-\mathrm{n})$

The predicted value of the molar volume, $\mathrm{V}_{0}$, is given by

$$
\mathrm{V}_{0}=\mathrm{F}_{0}^{\mathrm{T}} \hat{\mathrm{v}}
$$

where $F_{0}$ is the vector of coefficients for the molecule of interest, and the variance for the predicted molar volume is given by

$$
\operatorname{Var}\left(\mathrm{V}_{0}\right)=\sigma^{2}\left[1+\mathrm{F}_{0}^{\mathrm{T}}\left(\mathrm{A}^{\mathrm{T}} \mathrm{A}\right)^{-1} \mathrm{~F}_{0}\right]
$$

The standard deviation of the predicted molar volume is the square root of this variance.

If Eq. (3) is used to obtain a solution to Eq. (2), the calculated molar volumes for some compounds differ substantially from the observed volumes. The reasons for these outliers are varied. Statistically, a few calculated molar volumes will deviate substantially from the observed values. However, these outliers also may be caused by errors in the Cambridge Crystallographic Files data. The detection and treatment of these outliers have been the subject of much concern ${ }^{28,29}$ Nevertheless, these outliers should be included but with less weight than the rest of the points. Several iterative methods exist to deal with outlying points, and a review of computational approaches to robust linear regression is given by Holland and Welsch. ${ }^{30}$ One of these methods, originally developed by Huber, ${ }^{31}$ seems to be the most stable for a wide range of problems and is also one of the simplest.

In Huber's scheme a loss function, $\phi(x)$, is defined so that outliers are included with less weight than the bulk of the points. The vector, $\hat{v}$, then minimizes the quantity,

$$
\sum_{j=1}^{m} \phi\left[\frac{1}{\sigma}(V-A \hat{v})\right]
$$

The solution to Expression (7) usually is calculated by iterative methods. One iteration scheme is given by

$$
\hat{\mathbf{v}}^{(i+1)}=\hat{\mathbf{v}}^{(\mathbf{i})}+\sigma\left(\mathrm{A}^{\mathrm{T}} \mathrm{A}\right)^{-1} \mathrm{~A}^{\mathrm{T}} \Psi\left[\frac{1}{\sigma}\left(\mathrm{V}-\mathrm{A} \hat{\mathbf{v}}^{(\mathrm{i})}\right)\right],
$$

where $\hat{v}^{(i)}$ is the solution vector for the $\mathrm{i}$-th iteration, and $\psi(\mathrm{x})=\phi^{\prime}(\mathrm{x})$.

The weight function used in all calculations is given by

$\psi(x)=\left\{\begin{array}{ll}x & |x| \leqq H \\ \operatorname{sgn}(x) H & |x|>H\end{array}\right.$,

where the "tuning constant," $\mathrm{H}$, has the value 1.345 . The results were relatively insensitive to the value assumed for $\sigma$ and converged rapidly.

The method just described finds the set of constituent volumes that minimizes deviations between the calculated and observed molar volumes for the basis compounds. However, this set may not be optimal for minimizing deviations between the calculated and observed densities. That is, the quantity

$\sum_{j=1}^{m}\left(\rho_{j}^{\text {obs }}-\rho_{j}^{\text {calc }}\right)^{2}$

is minimized where

$\rho_{\mathrm{j}}^{\text {calc }}=\mathrm{M}_{\mathrm{j}} / \mathrm{V}_{\mathrm{j}}$,

and $\mathrm{M}_{\mathrm{j}}$ is the molecular weight and $\mathrm{V}_{\mathrm{j}}$ is given by Eq. (1). Expression (10) now requires a multidimensional, nonlinear least-squares method for its solution. A variety of nonlinear least-squares methods exists; the one used here is based on locating the minimum by the very efficient conjugate-gradient technique. ${ }^{32}$ The values for the constituent volumes calculated with the linear least-squares method were used as an initial guess for the nonlinear least-squares method. For convenience, minimization of the volume deviation is called the linear least-squares calculation, and minimization of the density deviation is the nonlinear least-squares calculation.

Before I present results for various definitions of the constituent volumes in the next section, I first describe the compounds that make up the basis set.

The Cambridge Crystallographic Files contain a large amount of information on compounds whose crystal structures have been determined experimentally since about $1936 . .^{33-35}$ These data are contained in three files. 
The first contains information related to the compound name and the bibliographic source of the data. The second contains information related to the atom types, bond types, and how the atoms in the molecule are connected to one another. The third contains information related to the unit cell and all Cartesian coordinates of the atoms in the unit cell. The entries corresponding to a particular compound in each file are related to one another by a six-letter reference code, or REFCODE. If the crystal structure was investigated by another author or the same author, or if the compound exists as different polymorphs, then two digits are added to the six-letter REFCODE so that the compounds may be differentiated. Information is needed from all three files for the present analysis.

The files are constantly updated as new compounds are added. In addition, efforts have been made to ensure that the files are as error-free as possible. ${ }^{36}$ Nevertheless, errors became apparent because the densities calculated (for a substantial number of compounds) with the unit cell parameters did not agree with those reported by the authors. The reasons for the disagreement are varied and include: wrong formulas used by the author to calculate the unit cell volume; the wrong $z$ value (number of molecules in the unit cell) in the file; transposition errors in the unit cell data in the file; and file data were for a different compound than the one intended. These are only a few of the many errors found, but for a number of compounds no reason for the discrepancies could be found.

Thus, the compounds used in the basis set were selected as follows. First, only compounds composed of hydrogen, carbon, nitrogen, oxygen, or fluorine were selected: and these also were required to be nonpolymeric and nonionic, and to consist of a single residue. About 4000 compounds satisfied these criteria, and of these, about half contained neither the unit cell data nor the author's calculated density; or else the density calculated from the unit cell parameters did not agree with the author's. After these compounds were deleted, the basis set consisted of 2051 error-free compounds. A list of these 2051 compounds that make up the basis set is given in a set of microfiche at the end of this report. The list contains the name, density, and formula for each compound in the basis set. Figure la shows the distribution of the molar volumes for the 2051 compounds, and Fig. 16 shows the densities.

The data base will be expanded to include ionic, multiple-residue, and other atoms in future work.
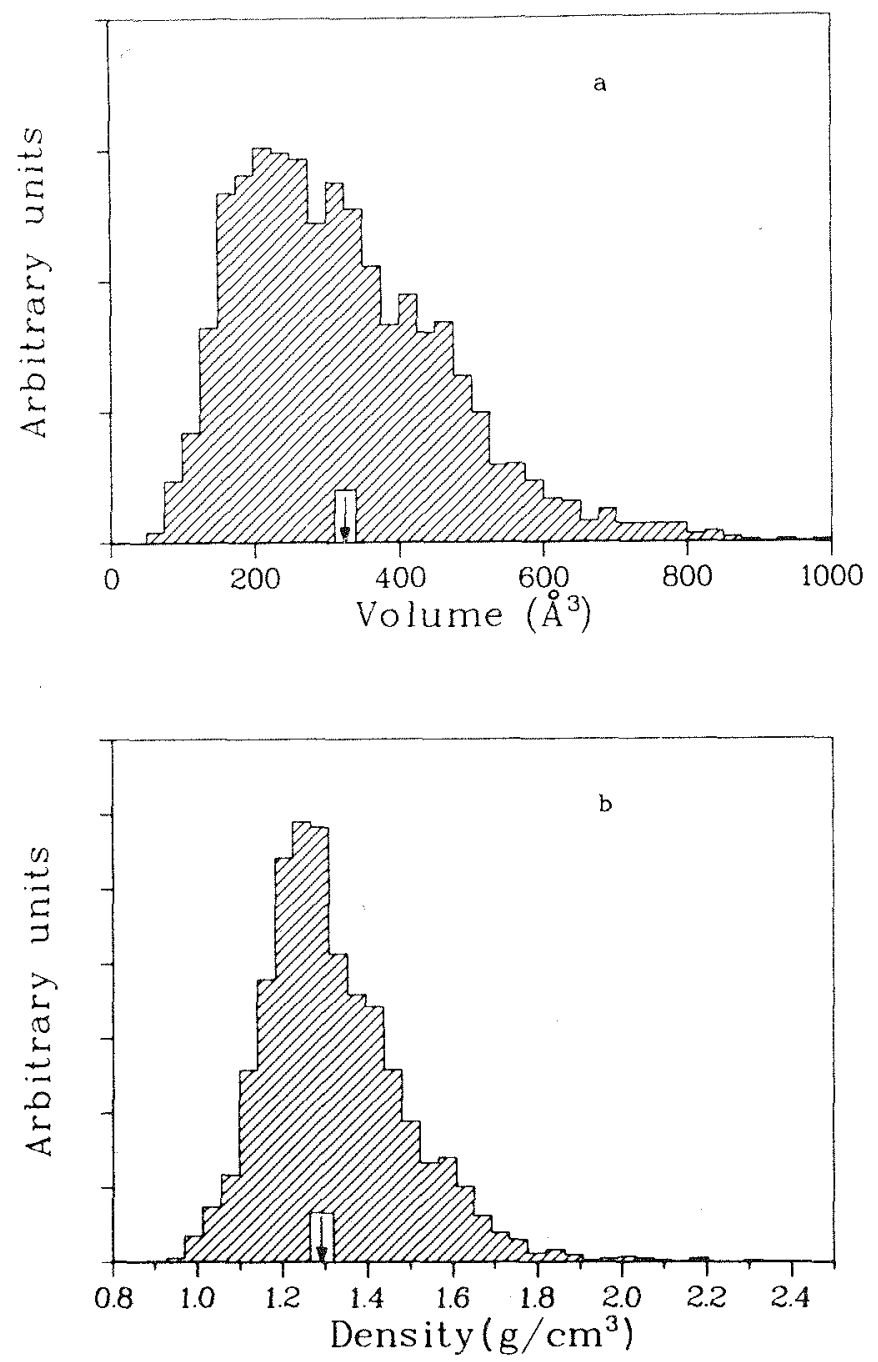

Fig. 1.

Distribution of crystal volumes (a) and densities (b) for the 2051 compounds in the basis set. Arrows point to average values of about $325 \mathrm{~A}^{3}$ for volume and $1.29 \mathrm{~g} / \mathrm{cm}^{3}$ for density.

\section{RESULTS}

This section presents criteria and results for various definitions of the constituent volumes.

Each set of constituent volumes had the following properties. First, each set was simply defined and contained as few volumes as possible. (A prime purpose of the empirical method is the identification of classes of compounds, or constituent groups, that tend to make dense compounds. Usually this identification is made more transparent by having only a few parameters with intuitive meanings.) Second, the molar volume for each 


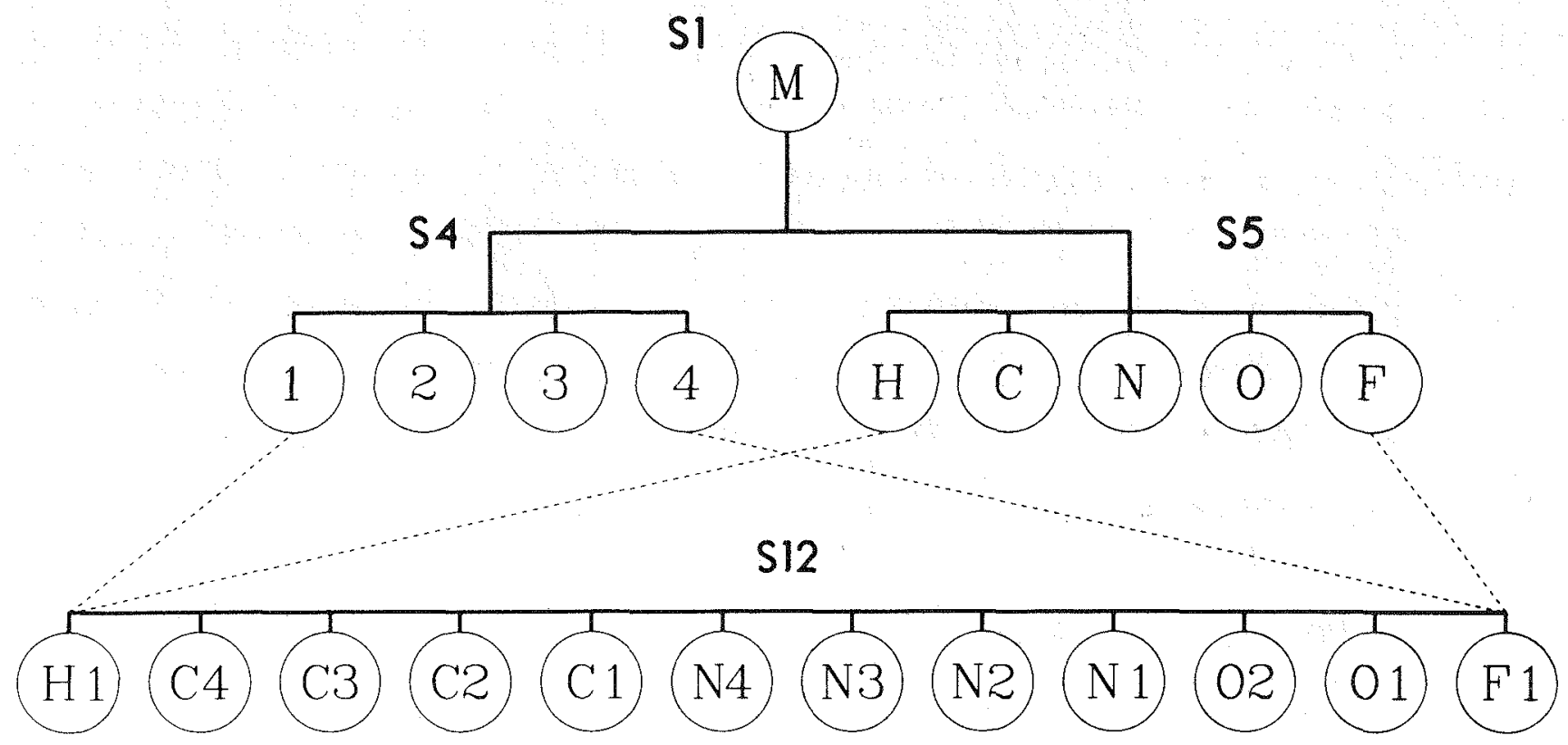

Fig. 2.

Definitions of the constituent volumes for sets S1, S4, S5, and S12.

compound in the basis set was composed, unambiguously, of the constituent volumes under consideration. That is, the set of constituent volumes spanned all types of compounds in the basis set regardless of the complexity or uniqueness of the compound. Third, the constituent volume corresponded to a physical entity and hence to a real volume. Thus, values for all constituent volumes were positive, and this gave a check on the validity of the definitions. Also one is not misled into proposing that a molecule is unusually dense on the basis of its having many negatively valued contributions to its molar volume. [Note that, although the constituent volumes should be positive, none of the calculations were constrained so as to force this condition. It should be noted also that the crystallographic unit cell dimensions are given in units of angstroms $(\AA)$, and thus crystal volumes $\left(\AA^{3} /\right.$ molecule) rather than molar volumes $\left(\mathrm{cm}^{3} /\right.$ mole) were fitted. The conversion between them is $V_{\text {crystal }}$ $\left(\AA^{3} /\right.$ molecule $)=0.6023 \mathrm{~V}_{\text {molar }}\left(\mathrm{cm}^{3} /\right.$ mole $\left.).\right]$

The simplest of all definitions assumes that all atoms have the same volume, regardless of type. Thus, the first set in Table I, denoted S1, consists of just one constituent volume. Also shown in the table are: (1) the frequency with which the constituent volume was found (in this case, the number is also the number of atoms in all compounds in the basis set); (2) the linear least-squares value for the volume (with its standard deviation); and (3) the nonlinear least-squares result for the volume.
This primitive set can be subdivided: one set (S4) defines those atoms that have form one, two, three, or four bonded neighbors; alternatively, another set (S5) defines volumes according to atom type, that is, a set of five constituent volumes corresponding to the volumes occupied by hydrogen, carbon, nitrogen, oxygen, or fluorine atoms.

The set of 12 constituent volumes ( $\mathrm{S} 12)$ contains the "chemical cross product" of sets S4 and S5; that is, a carbon atom with four bonded neighbors (C4), or three (C3), and so forth (Table I). The relationship between these sets is shown schematically in Fig. 2.

A histogram of the percent relative errors in the densities for the 2051 basis compounds is shown for each of the sets, S1, S4, S5, and S12 (Figs. 3a-d). As more meaningful constituent volumes are defined, the percent error rapidly decreases. The linear least-squares variances [calculated using Eq. (4)] for S1, S4, S5, and $\mathrm{S} 12$ are $888.8,360.6,280.3$, and 180.5 , respectively.

The four sets are useful if one has a very limited knowledge of the compound. I will assume, however, that the structural formula is known so that $\mathrm{S} 12$ can be expanded to include different bonding environments, thus providing set S34 (Table II). For example, a carbon atom that forms two single bonds and one double bond is differentiated from a carbon atom that forms two aromatic bonds and a single bond. To aid in the specifications of the atoms' bonding environment, I 

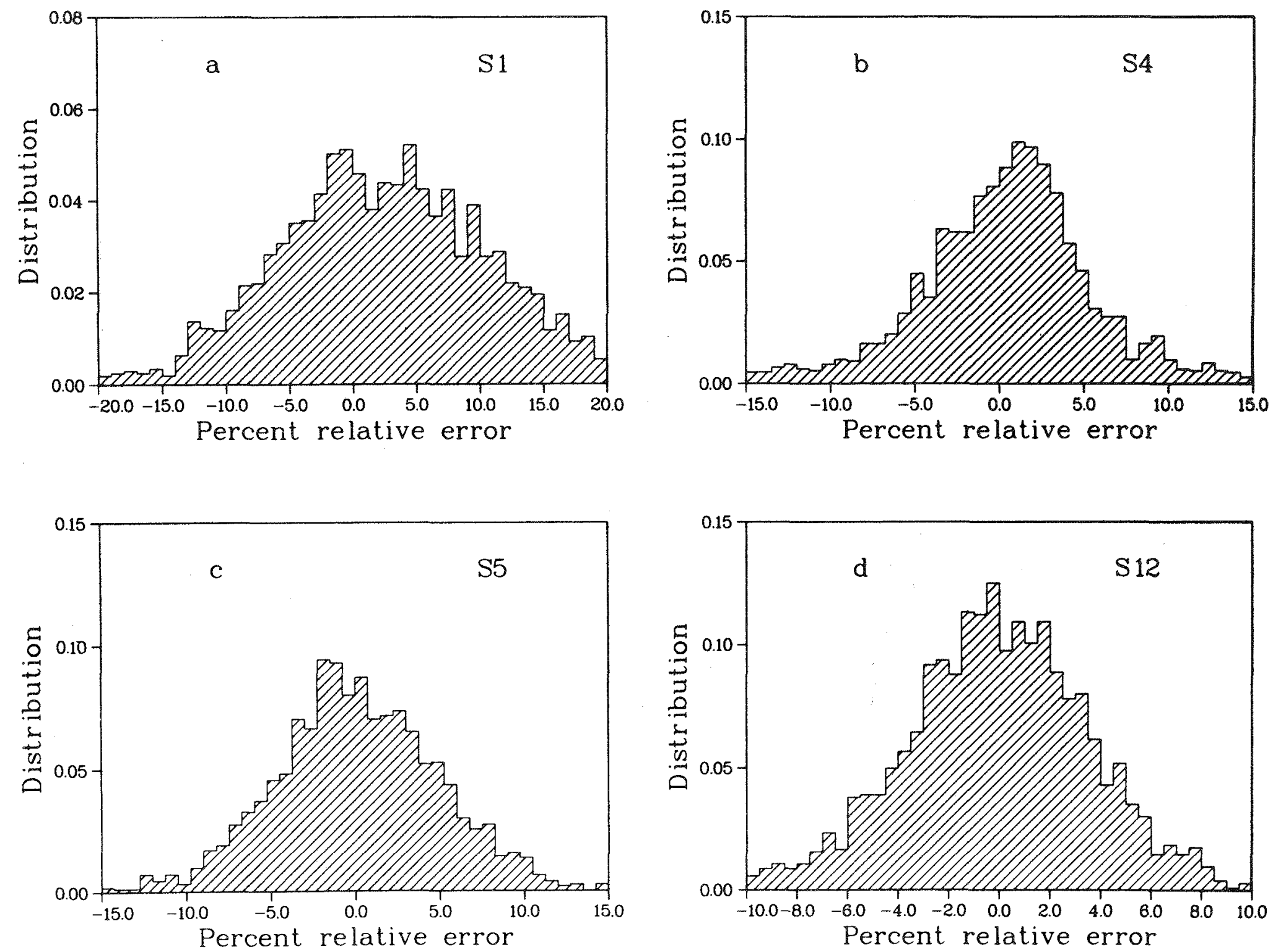

Fig. 3.

Percent relative errors of the linear least-squares calculated densities for constituent volume sets S1 (3a), S4 (3b), S5 (3c), and S12 (3d). 

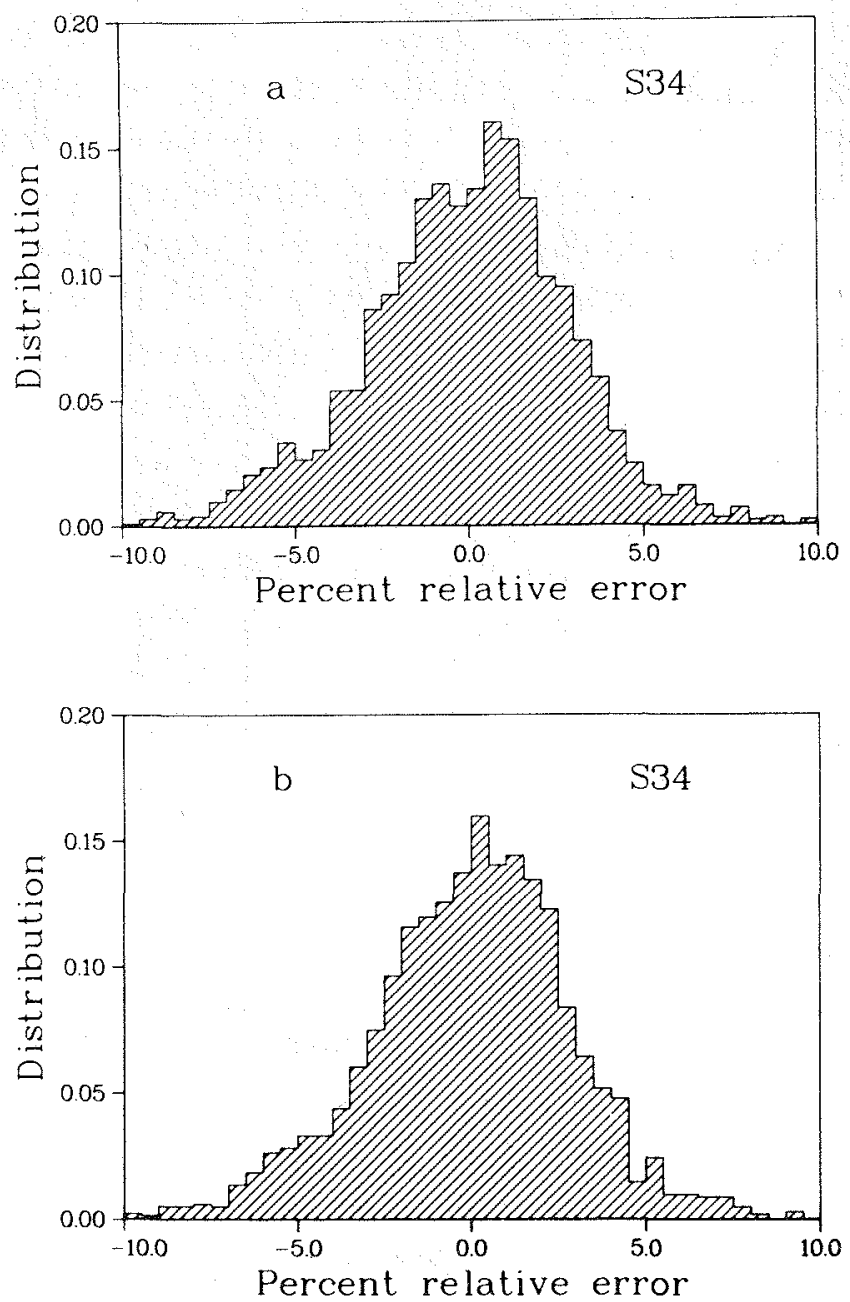

Fig. 4.

Percent relative error of the linear (a) and nonlinear (b) least-squares calculated densities for constituent volume set S34.

denote a single, double, or triple bond by 1,2 , or 3 , respectively, and if the bonds are part of a ring system, by $-1,-2$, or -3 , respectively. An aromatic bond (as in benzene) is denoted by -5 as it also must be part of a ring system. Conjugated bonds are denoted by 7 or -7 , the latter if the bond is part of a ring system. Thus, $O(2)$ represents an oxygen atom with one double bond, $\mathrm{O}(1,1$,$) two single bonds, and \mathrm{O}(-1,-1)$ two single bonds that are also part of a ring system. Some of the bonding environments correspond to extremely rare situations, such as $\mathrm{C}(-1,-3), \mathrm{C}(-2,-2)$, or $\mathrm{N}(1,1,1,1$,$) ,$ and some of these are grouped together.

Definitions of constituent volumes, the frequency with which these volumes are found in the set of basis compounds, and the values for the constituent volumes are given in Table II. Some values are based on a small number of atoms $(<200)$ and have correspondingly large standard deviations. Figures $4 \mathrm{a}$ and $\mathrm{b}$ show the distribution of the relative density errors for the linear and nonlinear results for S34. The standard error of about $3 \%$ can be deduced from these graphs. The variance for this set, calculated using Eq. (4), is 114.8 so that the expected error in a calculated crystal volume is about $10.7 \AA^{3}$. Details of the calculations and the calculated densities for the basis compounds for all five sets of constituent volumes are given in a set of microfiche at the end of this report.

It is of interest to compare these results, where possible, with those obtained by other investigators, such as Kitaigorodsky who has obtained a set of constituent volumes based on the calculation of molecular volumes. $^{24}$

The present results include, of course, a contribution from the void between the molecules and hence each constituent volume can be thought of as having its own "packing coefficient." The comparisons with Kitaigorodsky's results are given in Table III. The packing coefficients for the common carbon-hydrogen groups are in the range $0.66-0.77$, which is the range of packing coefficients found by Kitaigorodsky for organic molecules. Values for these constituent volumes, obtained by Immirizi and Perini, ${ }^{22}$ are in agreement with the present results. This agreement indicates that the values obtained represent physical volumes of atoms in specific bonding environments and are independent of the molecular system.

A comparison also may be made with some of Tarver's ${ }^{21}$ results, based on his analysis of aromatic explosives. He defined constituent volumes in terms of the aromatic carbon atom with an attached constituent chemical group. Table IV lists the chemical groups found in his set of 25 explosives basis compounds and the calculated values using the $\mathrm{S} 34$ results.

\section{APPLICATIONS TO EXPLOSIVES}

Here I apply the results of the previous sections to explosives and explosives-related compounds. Figure 5 gives an example the calculation of the density for DATNBZ (DATB-Diamino trinitrobenzene). The values used for the constituent volumes are for S34 (Table II). Note that the bonds between the nitrogen and the oxygen atoms in an $-\mathrm{NO}_{2}$ group are considered double bonds and hence nitrogen is denoted as $\mathrm{N}(2,2,1)$. 


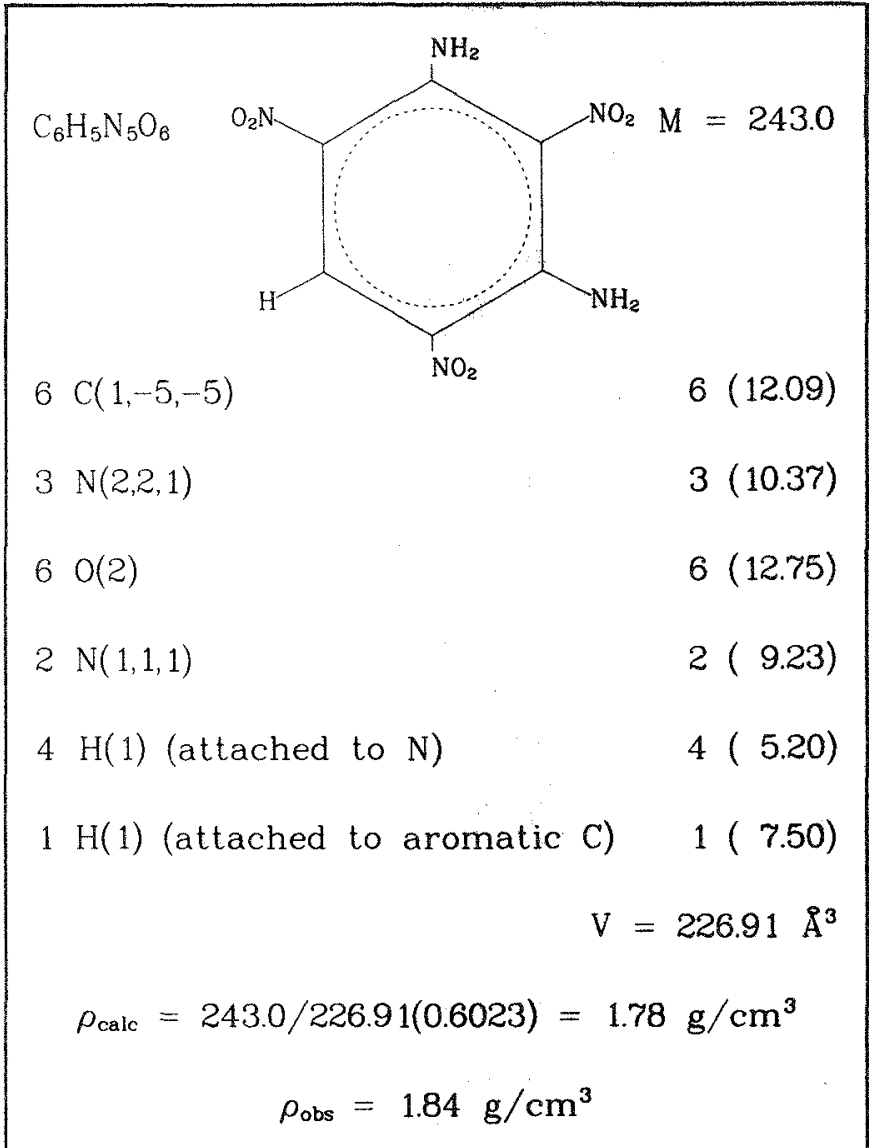

Fig. 5.

Sample calculation for DATB using the \$34 linear least-squares results.

Molecular structures for explosives whose crystal structures have been determined experimentally are considered first. Usually investigators of these crystal structures calculated the bulk density from the unit cell parameters and also measured the density independently (usually by flotation). Hence the densities are presumed correct even if other values are given in the literature. For example, Meyer ${ }^{37}$ lists the density of DINA as $1.49 \mathrm{~g} / \mathrm{cm}^{3}$ whereas the crystallographic data yield $1.66 \mathrm{~g} / \mathrm{cm}^{3}$.

Table $\mathrm{V}$ lists the calculated densities for these compounds for the linear and nonlinear constituent volume sets for S34. The percent relative density error is given in parentheses and is defined by

Rel. Err. $=100\left(\rho^{\text {obs }}-\rho^{\mathrm{calc}}\right) / \rho^{\mathrm{obs}}$.

Figures $6 a$ and $b$ show the distribution of these errors for the compounds listed in Table V.
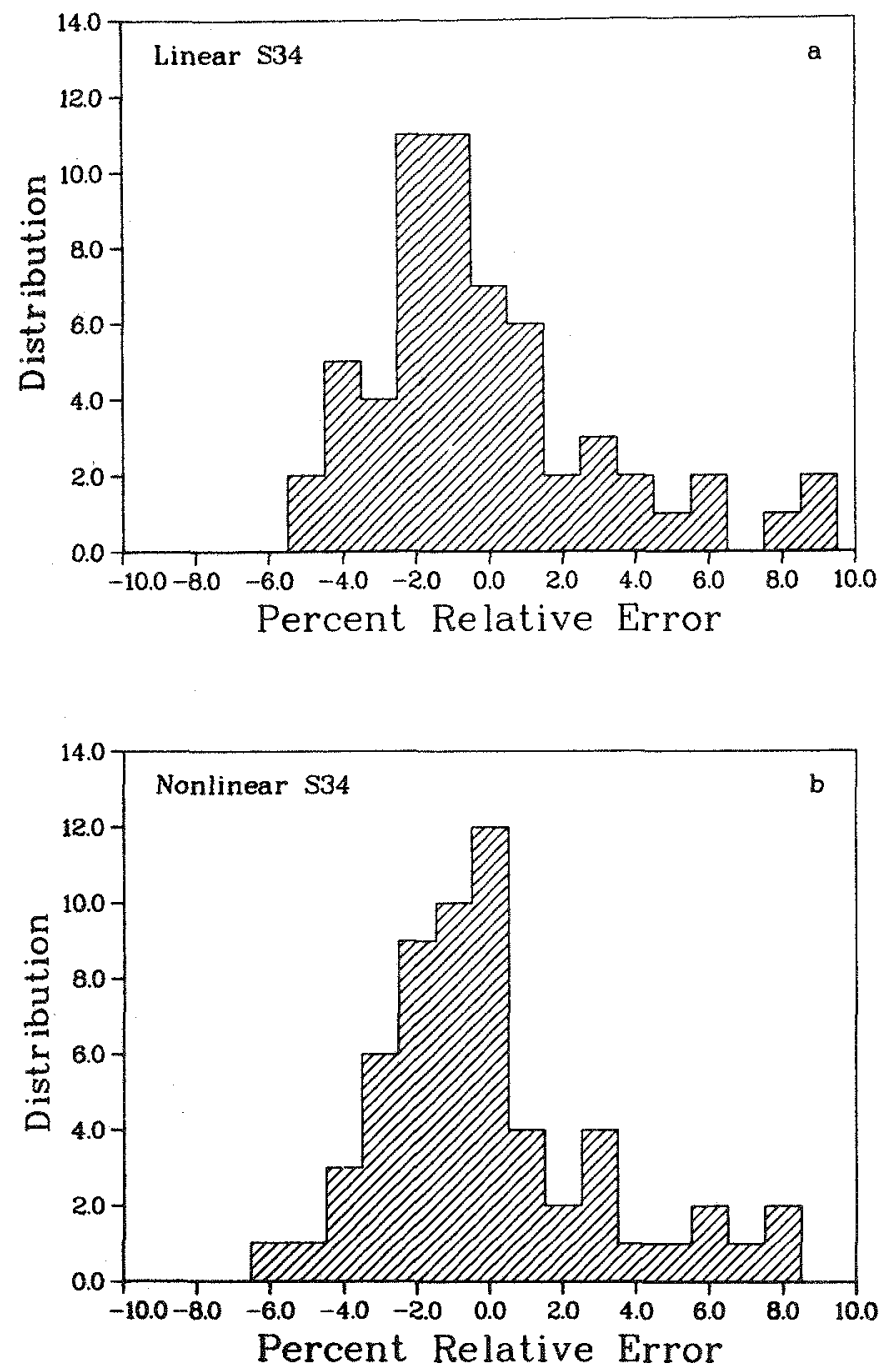

Fig. 6.

Percent relative errors for the compounds listed in Table $\mathrm{V}$ using the S34 linear results (a) and nonlinear results (b).

Some of the compounds listed in Table $\mathrm{V}$ have more than one form, and the relative errors are included in Figs. $6 a$ and $b$. The observed densities for these compounds are: $\mathrm{HMX}\left(\mathrm{C}_{4} \mathrm{H}_{8} \mathrm{~N}_{8} \mathrm{O}_{8}\right)-\alpha$-form $1.84 \mathrm{~g} / \mathrm{cm}^{3}, \beta$ form $1.89 \mathrm{~g} / \mathrm{cm}^{3}, \gamma$-form $1.78 \mathrm{~g} / \mathrm{cm}^{3}, \delta$-form $1.76 \mathrm{~g} / \mathrm{cm}^{3}$; PETN $\left(\mathrm{C}_{5} \mathrm{H}_{8} \mathrm{~N}_{4} \mathrm{O}_{12}\right)$-form I $1.78 \mathrm{~g} / \mathrm{cm}^{3}$, form II $1.72 \mathrm{~g} / \mathrm{cm}^{3}$; and $\mathrm{HNAB}\left(\mathrm{C}_{12} \mathrm{H}_{4} \mathrm{~N}_{8} \mathrm{O}_{12}\right)$-form I $1.80 \mathrm{~g} / \mathrm{cm}^{3}$, form II $1.74 \mathrm{~g} / \mathrm{cm}^{3}$.

Table VI lists heterocyclic explosives compounds prepared at Los Alamos, whose densities have been observed. One compound of interest in this list is pentanitroaniline $\left(\mathrm{C}_{6} \mathrm{H}_{2} \mathrm{~N}_{6} \mathrm{O}_{10}\right)$. This compound has an observed density of $1.77 \mathrm{~g} / \mathrm{cm}^{3}$ (measured by flotation), which differs substantially from the predicted value of $1.95 \mathrm{~g} / \mathrm{cm}^{3}$. Table VII lists the observed and calculated 
densities for other nitroanilines and for hexanitrobenzene. The calculated values are in very good agreement for all of these compounds except pentanitroaniline. The reasons for this discrepancy include erroneous measurement (pentanitroaniline easily hydrolyzes), lattice defects, and strained or abnormal crystal structure. The density has been remeasured recently (by W. P. Norris, at the Naval Weapons Center, using a gas pycnometer) and found to be $1.86 \mathrm{~g} / \mathrm{cm}^{3}$. Table VIII contains similar information for explosives given in various handbooks. ${ }^{37-40}$

Figure 7 shows the molecular structures for proposed explosives and their existing related compounds. (Data from Refs. 20 and 41 and from R. N. Rogers of Los Alamos.) Table IX lists densities calculated for these compounds using the constituent volume values given for S34 (Table II).

Figure 8 gives the base structures for some "prisanes" that are of interest in the synthesis of proposed explosives as studied by E. E. Gilbert of the US Army Armament Research and Development Command. These are compounds that generally have strained, symmetric structures. It is not known whether all of these molecules are stable enough to be synthesized nor or the degreee to which they can be nitrated. Table $\mathrm{X}$ lists the densities calculated with the S34 linear and nonlinear results for the base structure and the fully nitrated structure. Parameters are also given so that one can easily calculate the density of any partially nitrated compound. Here $\mathrm{k}$ is the number of $-\mathrm{NO}_{2}$ groups in the molecule where $\mathrm{k}$ is between zero and $\mathrm{k}_{\max }$. The densities are calculated from

$\rho_{\text {linear }}=\frac{a+45 k}{c+18.01 k}$

and

$\rho_{\text {nonlinear }}=\frac{a+45 \mathrm{k}}{\mathrm{c}^{\prime}+17.79 \mathrm{k}}$

where $\mathrm{a}, \mathrm{c}$, and $\mathrm{c}^{\prime}$ are given in Table $\mathrm{X}$ for each prisane.

\section{CONCLUSIONS}

A simple empirical method has been developed to predict the density of organic crystalline compounds and also to estimate the probable error in the predicted density. The method may be applied to compounds that contain hydrogen, carbon, nitrogen, oxygen, and fluorine atoms. The probable error in a predicted density for both explosive and nonexplosive compounds is about $3 \%$.

Two sets of values were obtained for the constituent volumes; the first set is based on minimizing the errors between the observed and calculated crystal volumes (linear) and the second set is based on minimizing the errors between the observed and calculated densities (nonlinear). Both sets of values yield abnut the same predicted densities (usually within $\pm 0.01 \mathrm{~g} / \mathrm{cm}^{3}$ ). 


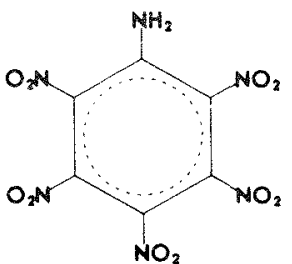

PNA

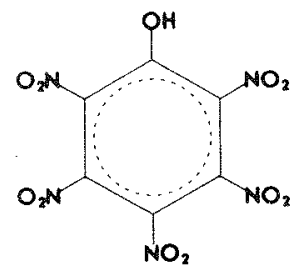

PNP

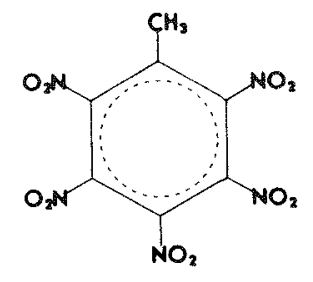

PNT

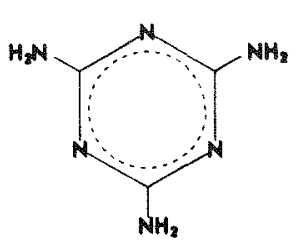

MELAMI

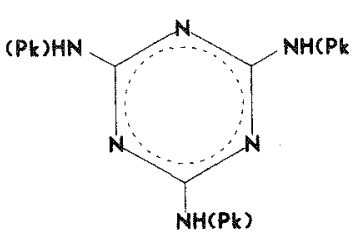

TPM

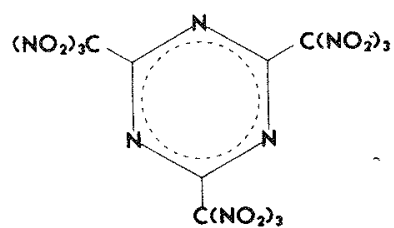

TTNM<smiles></smiles>

TNST

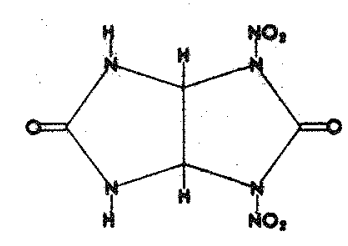

DINGU

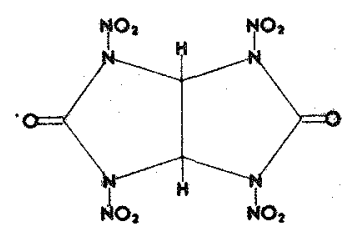

SORGUYL

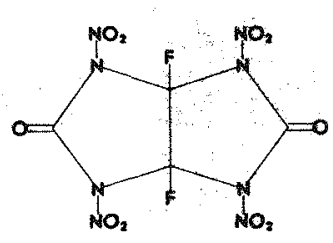

DTGU

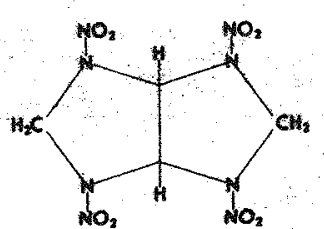

BCHMX

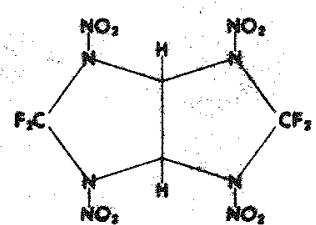

TTGU<smiles>O=[N+]([O-])C1CCN([N+](=O)[O-])C2C1N([N+](=O)[O-])CCN2[N+](=O)[O-]</smiles>

TAD

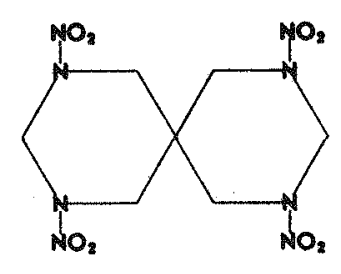

Co6

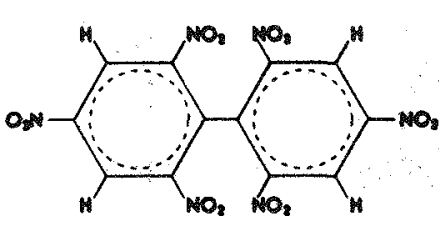

HNBP

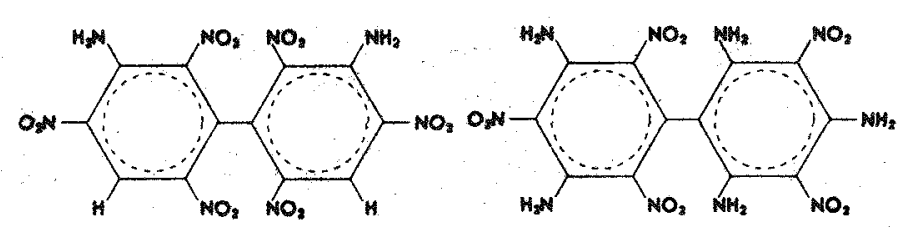

DIPAM

TATB2

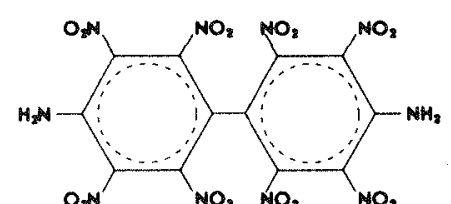

$\mathrm{CL} 12$

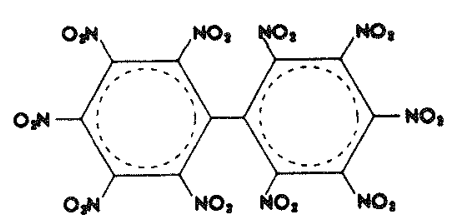

DNBP

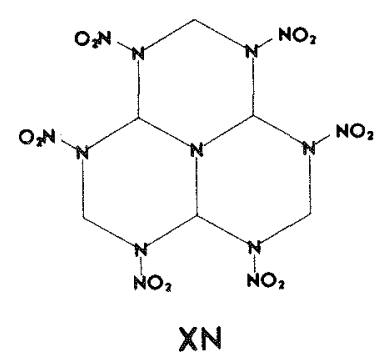

Fig. 7.
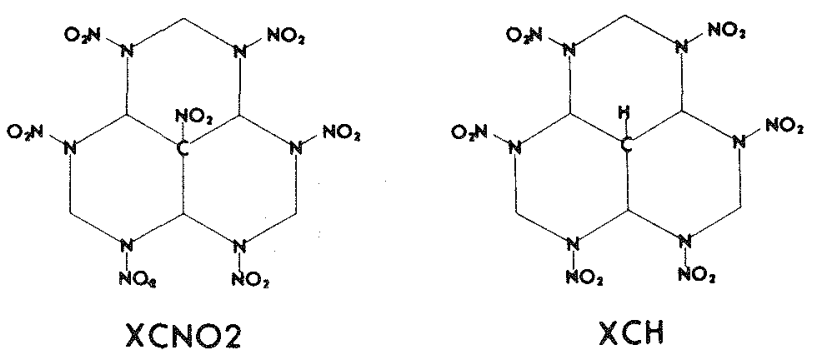


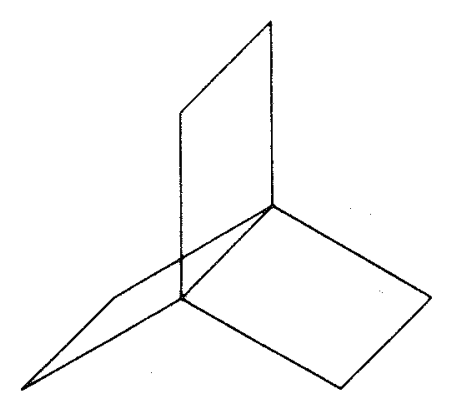

PROP

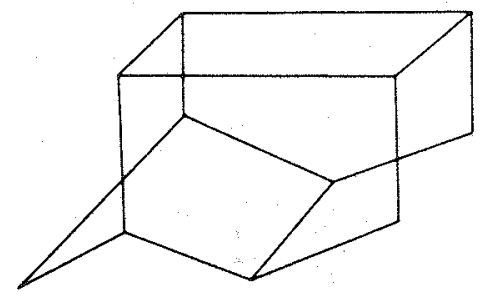

PCU

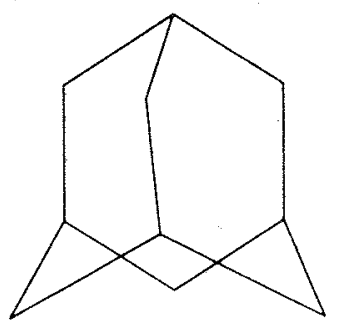

ADAMAN

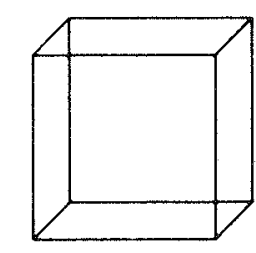

CUBANE

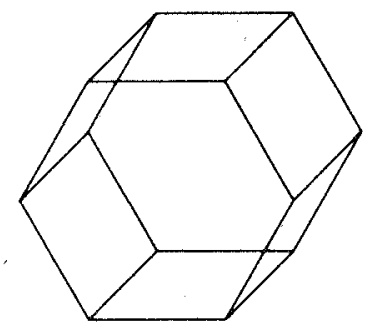

PRIS6

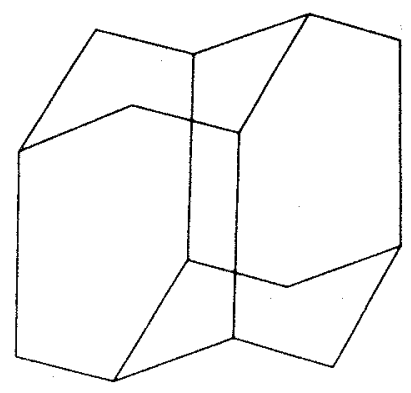

CONGRS

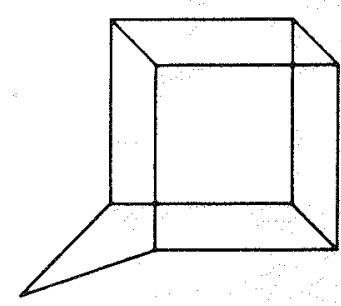

$\mathrm{BCU}$

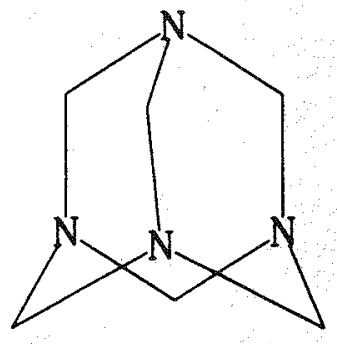

TAM

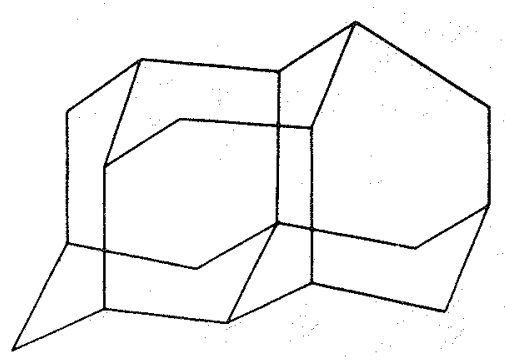

TRI A MT

Fig. 8.

Structures of some base prisane of interest in the synthesis of proposed explosives. 
TABLE I. Results for Constituent Volume Sets S1, S4, S5, and S12

\begin{tabular}{lllll} 
& & & \multicolumn{2}{c}{ Crystal Volume } \\
Set & Definition & Linear & Nonlinear \\
No. & Frequency & $\left(\AA^{3}\right)$ & $\left(\AA^{3}\right)$ \\
\hline
\end{tabular}

S1

M Any atom

72017

$9.208(0.017)$

9.555

$\mathrm{S} 4$

V1 Atom with one bonded neighbor

37441

4048

V2 Atom with two bonded neighbors

17639

Atom with three bonded neighbors

12889

$\begin{array}{rrr}9.881 & (0.172) & 10.045 \\ 10.627 & (0.204) & 11.496 \\ 10.476(0.135) & 10.339 \\ 5.360(0.310) & 5.204\end{array}$

S5

V4 Atom with four bonded neighbors

34149

29187

2466

5957

258

$5.250(0.065)$

5.015

Carbon atom

$13.406(0.077)$

13.755

Oxygen atom

Fluorine atom

$10.663(0.144) \quad 10.110$

12.685

$11.794(0.333) \quad 11.839$

H1 Hydrogen atom with one bonded neighbor

C4 Carbon atom with four bonded neighbors

34149

12850

Carbon atom with three bonded neighbors

16031

Carbon atom with two bonded neighbors

Carbon atom with one bonded neighbor

303

Nitrogen atom with four bonded neighbors

3

N4

Nitrogen atom with three bonded neighbors

39

Nitrogen atom with two bonded neighbors

1608

Nitrogen atom with one bonded neighbor

642

177

Oxygen atom with two bonded neighbors

3103

Oxygen atom with one bonded neighbor

2854

$\begin{array}{rrr}8.817 & (0.134) & 8.098 \\ 6.968 & (0.237) & 8.474 \\ 10.972 & (0.100) & 11.448 \\ 15.445(0.625) & 15.909 \\ 26.463(6.046) & 26.411 \\ -9.218(2.238) & -7.979 \\ 5.885(0.354) & 5.951 \\ 12.837(0.421) & 13.290 \\ 18.891(0.872) & 17.693 \\ 9.125(0.169) & 7.969 \\ 15.861(0.253) & 15.023 \\ 15.240(0.294) & 14.278\end{array}$


TABLE II. Results for Constituent Volume Set S34

\begin{tabular}{|c|c|c|c|c|}
\hline & \multirow[b]{2}{*}{ Definition } & \multirow[b]{2}{*}{ Frequency } & \multicolumn{2}{|c|}{ Constituent Volume } \\
\hline & & & $\begin{array}{l}\text { Linear } \\
\left(\AA^{3}\right)\end{array}$ & $\begin{array}{c}\text { Nonlinear } \\
\left(\AA^{3}\right)\end{array}$ \\
\hline$v_{1}$ & $\mathrm{H}(1)$ bonded to a nonaromatic carbon & 25087 & $5.981(0.298)$ & 6.725 \\
\hline$v_{2}$ & $H(1)$ bonded to an aromatic carbon & 6693 & $7.499(0.420)$ & 8.301 \\
\hline $\mathrm{v}_{\mathbf{3}}$ & $\mathrm{H}(1)$ bonded to a nitrogen & 992 & $5.199(0.460)$ & 5.461 \\
\hline $\mathbf{v}_{4}$ & $H(1)$ bonded to an oxygen & 1377 & $0.366(0.398)$ & 1.457 \\
\hline$v_{5}$ & $C(1,1,1,1)$ & 5246 & $13.390(0.623)$ & 12.036 \\
\hline$v_{8}$ & $C(1,1,-1,-1)$ & 5453 & $11.709(0.567)$ & 10.340 \\
\hline $\mathrm{v}_{\gamma}$ & $C(1,-1,-1,-1)$ & 1926 & $9.755(0.351)$ & 9.101 \\
\hline$v_{B}$ & $C(-1,-1,-1,-1)$ & 225 & $9.673(0.620)$ & 9.991 \\
\hline$v_{8}$ & $C(2,1,1)$ or $C(1,1,1)$ or $C(7,1,1)$ & 1829 & $14.565(0.362)$ & 13.922 \\
\hline$v_{10}$ & $C(1,-1,-2)$ & 2102 & $13.288(0.288)$ & 12.641 \\
\hline$v_{11}$ & $\mathrm{C}(2,-1,-1)$ or $\mathrm{C}(1,-1,-1)$ & 1271 & $12.654(0.416)$ & 12.029 \\
\hline$v_{12}$ & $C(-1,-1,-2)$ & 495 & $10.410(0.330)$ & 10.397 \\
\hline $\mathrm{v}_{13}$ & $C(1,-5,-5)$ or $C(1,-7,-7)$ or $C(2,-5,-5)$ & 8555 & $12.094(0.326)$ & 11.536 \\
\hline$v_{14}$ & $C(-1,-5,-5)$ & 1313 & $10.618(0.214)$ & 10.568 \\
\hline$v_{15}$ & $C(-5,-5,-5)$ & 466 & $10.370(0.237)$ & 10.032 \\
\hline $\mathrm{v}_{18}$ & $C(3,1)$ or $C(2,2)$ & 251 & $16.579(0.676)$ & 17.485 \\
\hline $\mathrm{V}_{17}$ & $C(-1,-3)$ or $C(-2,-2)$ or $C(-3,-7)$ & 52 & $15.963(0.742)$ & 14.852 \\
\hline$v_{18}$ & $C(3)$ & 3 & $24.831(4.868)$ & 24.811 \\
\hline $\mathrm{v}_{19}$ & $\mathrm{~N}(1,1,1,1)$ & 34 & $0.887(2.364)$ & 0.232 \\
\hline $\mathrm{v}_{20}$ & $\mathrm{~N}(1,1,-1,-1)$ & 5 & $4.016(4.872)$ & 3.763 \\
\hline $\mathrm{v}_{21}$ & $\mathrm{~N}(2,2,1)$ & 218 & $10.368(0.857)$ & 10.768 \\
\hline$v_{22}$ & $\mathrm{~N}(1,-5,-5)$ or $\mathrm{N}(1,-7,-7)$ & 38 & $4.570(1.504)$ & 4.844 \\
\hline$v_{23}$ & $\mathrm{~N}(1,-1,-2)$ or $\mathrm{N}(2,-1,-2)$ & 20 & $13.118(2.210)$ & 13.635 \\
\hline $\mathrm{v}_{24}$ & $\mathrm{~N}(1,1,1)$ or $\mathrm{N}(2,1,1)$ & 495 & $9.234(0.706)$ & 9.083 \\
\hline$v_{\Upsilon \complement}$ & $\mathrm{N}(1,-1,-1)$ or $\mathrm{N}(1,-1,-7)$ or $\mathrm{N}(7,-1,-7)$ or $\mathrm{N}(2,-1,-1)$ & 697 & $9.798(0.464)$ & 8.884 \\
\hline$v_{28}$ & $\mathrm{~N}(-1,-1,-1)$ or $\mathrm{N}(-1,-7,-7)$ or $\mathrm{N}(-5,-5,-5)$ & 140 & $8.759(0.705)$ & 8.043 \\
\hline$v_{27}$ & $\mathrm{~N}(-5,-5)$ or $\mathrm{N}(-7,-7)$ & 155 & $12.268(0.664)$ & 12.188 \\
\hline$v_{28}$ & $\mathrm{~N}(2,1)$ or $\mathrm{N}(3,1)$ or $\mathrm{N}(1,1)$ or $\mathrm{N}(2,2)$ & 175 & $14.488(0.694)$ & 13.669 \\
\hline$v_{2 \vartheta}$ & $\mathrm{N}(-1,-2)$ or $\mathrm{N}(-1,-1)$ or $\mathrm{N}(-1,-7)$ & 312 & $11.941(0.509)$ & 12.812 \\
\hline$v_{30}$ & $N(3)$ or $N(2)$ & 177 & $15.599(0.864)$ & 15.007 \\
\hline$v_{31}$ & $O(1,1)$ & 2176 & $12.178(0.320)$ & 11.802 \\
\hline $\mathrm{v}_{32}$ & $O(-1,-1)$ or $O(-7,-7)$ or $O(-5,-5)$ & 927 & $12.172(0.266)$ & 11.462 \\
\hline$v_{33}$ & $O(2)$ or $O(1)$ & 2854 & $12.754(0.395)$ & 12.743 \\
\hline$v_{34}$ & $F(2)$ or $F(1)$ & 258 & $12.929(0.363)$ & 13.493 \\
\hline
\end{tabular}


TABLE III. Comparison of Constituent Volumes of Kitaigorodsky and of Immirizi and Perini with the Corresponding Linear Least-Squares S34 Results

\begin{tabular}{lccc}
\hline & Molecular Volume & \multicolumn{2}{c}{ Crystal Volume } \\
\cline { 2 - 4 } \multicolumn{1}{c}{ Constituent } & $\begin{array}{c}\text { Kitaigorodsky } \\
\left(\AA^{3}\right)\end{array}$ & $\begin{array}{c}\text { Linear } \\
\left(\AA^{3}\right)\end{array}$ & $\begin{array}{c}\text { Immirizi } \\
\text { \& Perini } \\
\left(\AA^{3}\right)\end{array}$ \\
\hline $\mathrm{C}$ (aromatic) & & & \\
$\mathrm{C}-\mathrm{H}$ (aromatic) & 8.4 & $12.09(0.70)^{\mathrm{a}}$ & 12.53 \\
$\mathrm{C}-\mathrm{H}$ (aliphatic) & 14.7 & $19.59(0.75)$ & $\ldots .$. \\
$\mathrm{CH}$ & 11.1 & $19.37(0.57)$ & 17.9 \\
$\mathrm{CH}$ & 17.1 & $25.35(0.68)$ & 24.8 \\
$>\mathrm{C}<$ & 23.5 & $31.33(0.75)$ & 31.7 \\
$-\mathrm{NO}_{2}$ & 5.0 & $13.39(0.37)$ & 11.0 \\
$-\mathrm{NH}_{2}$ & 23.0 & $35.88(0.64)$ & 35.2 \\
$\mathrm{~F}$ & 19.7 & $19.63(1.00)$ & 21.0 \\
$=\mathrm{C}<$ & 9.6 & $12.93(0.74)$ & 12.8 \\
$-\mathrm{C} \equiv$ & 13.1 & $14.57(0.90)$ & 13.7 \\
$\equiv \mathrm{N}$ & 5.9 & $16.58(0.36)$ & 15.3 \\
$\mathrm{H}$ & 10.0 & $15.60(0.64)$ & 16.0 \\
\hline & 2.0 & $5.98(0.33)$ & 6.9 \\
\hline
\end{tabular}

${ }^{a}$ Ratio of Kitaigorodsky molecular volume with present crystal volume. 
TABLE IV. Comparison of Constituent Volumes of Tarver for Aromatic Compounds with the Corresponding Linear Least-Squares S34 Results

\begin{tabular}{|c|c|c|}
\hline \multirow[b]{2}{*}{$\begin{array}{c}\text { Chemical } \\
\text { Group }\end{array}$} & \multicolumn{2}{|c|}{ Crystal Volume } \\
\hline & $\begin{array}{c}\text { Tarver } \\
\left(\AA^{3}\right) \\
\end{array}$ & $\begin{array}{c}\text { Linear } \\
\left(\AA^{3}\right) \\
\end{array}$ \\
\hline $\mathrm{C}-\mathrm{H}$ & 19.72 & 19.59 \\
\hline $\mathrm{C}-\mathrm{NO}_{2}$ & 49.31 & 47.97 \\
\hline$-\mathrm{OH}$ & 26.56 & 24.64 \\
\hline$-\mathrm{NH}_{2}$ & 26.01 & 31.73 \\
\hline $\mathrm{C}-\mathrm{CH}_{3}$ & 43.11 & 43.43 \\
\hline
\end{tabular}


TABLE V. Comparison of the Observed Densities with the Linear and Nonlinear Least-Squares S34Calculated Densities for Explosives Compounds of Known Crystal Structures

\begin{tabular}{|c|c|c|c|c|c|}
\hline \multirow[b]{2}{*}{ REFCODE } & \multirow[b]{2}{*}{ Formula } & \multirow[b]{2}{*}{ Compound Name } & \multirow{2}{*}{$\begin{array}{c}\text { Observed } \\
\text { Density } \\
\left(\mathrm{g} / \mathrm{cm}^{3}\right)\end{array}$} & \multicolumn{2}{|c|}{ Calculated Density } \\
\hline & & & & $\begin{array}{l}\text { Linear } \\
\left(\mathrm{g} / \mathrm{cm}^{3}\right)\end{array}$ & $\begin{array}{c}\text { Nonlinear } \\
\left(\mathrm{g} / \mathrm{cm}^{3}\right)\end{array}$ \\
\hline NTRGUA & $\mathrm{CH}_{4} \mathrm{~N}_{4} \mathrm{O}_{2}$ & NQ Nitroguanidine & 1.76 & $1.66(5.7)^{\mathrm{a}}$ & $1.66(5.7)$ \\
\hline DMN- & $\mathrm{C}_{2} \mathrm{H}_{6} \mathrm{~N}_{2} \mathrm{O}_{2}$ & DMN N.N-Dimethy lnitramine & 1.36 & $1.39(-2.2)$ & $1.36(0.0)$ \\
\hline DNEDAM & $\mathrm{C}_{2} \mathrm{H}_{8} \mathrm{~N}_{4} \mathrm{O}_{4}$ & EDNA $\mathrm{N}, \mathrm{N}^{\prime}$-Dinitroethylenediamine & 1.71 & $1.65(3.5)$ & $1.63(4.7)$ \\
\hline NIPYAZ & $\mathrm{C}_{3} \mathrm{H}_{3} \mathrm{~N}_{3} \mathrm{O}_{2}$ & $\mathrm{~N}$-Nitropyrazole $\mathrm{b}^{\mathrm{b}}$ & 1.59 & $1.59(0.0)$ & $1.59(0.0)$ \\
\hline MENFXN & $\mathrm{C}_{3} \mathrm{H}_{3} \mathrm{~N}_{3} \mathrm{O}_{4}$ & 3-Methyl-4-nitrof uroxan ${ }^{b}$ & 1.66 & $1.68(-1.2)$ & $1.67(-0.6)$ \\
\hline CTMTNA & $\mathrm{C}_{3} \mathrm{H}_{6} \mathrm{~N}_{6} \mathrm{O}_{6}$ & RDX Cyclo 1,3,5 trimethy lene-2,4,6 trinitramine ${ }^{b}$ & 1.81 & $1.77(2.2)$ & $1.78(1.7)$ \\
\hline AMPYRM & $\mathrm{C}_{4} \mathrm{H}_{6} \mathrm{~N}_{3}$ & 2- Aminopyrimidine $b$ & 1.34 & $1.37(-2.2)$ & $1.37(-2.2)$ \\
\hline DINA- & $\mathrm{C}_{4} \mathrm{H}_{8} \mathrm{~N}_{4} \mathrm{O}_{8}$ & DINA $2,2^{\prime}$-Dinitroxydiethy lnitramine & 1.66 & $1.64(1.2)$ & $1.64(1.2)$ \\
\hline OCHTET & $\mathrm{C}_{4} \mathrm{H}_{8} \mathrm{~N}_{8} \mathrm{O}_{8}$ & $\beta$-HMX Tetranitro-tetraazacyclooctane & 1.89 & $1.77(6.3)$ & $1.78(5.8)$ \\
\hline DNITPY & $\mathrm{C}_{5} \mathrm{H}_{3} \mathrm{~N}_{3} \mathrm{O}_{4}$ & 3,5-Dinitropyridineb & 1.65 & $1.68(-1.8)$ & $1.68(-1.8)$ \\
\hline AMNTPY & $\mathrm{C}_{5} \mathrm{H}_{5} \mathrm{~N}_{3} \mathrm{O}_{2}$ & 2-Amino-3-nitropyridine ${ }^{b}$ & 1.55 & $1.53(1.3)$ & $1.53(1.3)$ \\
\hline AMPYRD & $\mathrm{C}_{5} \mathrm{H}_{6} \mathrm{~N}_{2}$ & 2-Aminopyridine & 1.25 & $1.28(-2.4)$ & $1.27(-1.8)$ \\
\hline AMIPYR & $\mathrm{C}_{5} \mathrm{H}_{6} \mathrm{~N}_{2}$ & 3-Aminopyridine & 1.25 & $1.28(-2.4)$ & $1.27(-1.8)$ \\
\hline AMPYRE & $\mathrm{C}_{5} \mathrm{H}_{6} \mathrm{~N}_{2}$ & 4-A minopyridine ${ }^{b}$ & 1.27 & $1.28(-0.8)$ & $1.27(0.0)$ \\
\hline PERYTN & $\mathrm{C}_{5} \mathrm{H}_{8} \mathrm{~N}_{4} \mathrm{O}_{12}$ & PETN Pentaerythritol tetranitrate $b$ & 1.78 & $1.71(3.9)$ & $1.72(3.4)$ \\
\hline DNPMTA & $\mathrm{C}_{5} \mathrm{H}_{10} \mathrm{~N}_{8} \mathrm{O}_{4}$ & DPT Dinitropentamethy lenetetramine $b$ & 1.68 & $1.60(4.8)$ & $1.61(4.2)$ \\
\hline HNOBEN & $\mathrm{C}_{8} \mathrm{~N}_{8} \mathrm{O}_{12}$ & HNB Hexanitrobenzene & 1.99 & $2.01(-1.0)$ & $2.02(-1.5)$ \\
\hline DNBZFX & $\mathrm{C}_{6} \mathrm{H}_{2} \mathrm{~N}_{4} \mathrm{O}_{6}$ & 4,6-Dinitrobenzf uroxan $b$ & 1.76 & $1.85(-5.1)$ & $1.88(-5.7)$ \\
\hline FANTBZ & $\mathrm{C}_{6} \mathrm{H}_{2} \mathrm{~N}_{4} \mathrm{O}_{6} \mathrm{~F}_{2}$ & $(\mathrm{~N}, \mathrm{~N}-\mathrm{Difluoroamino}) \mathrm{tr}$ initro-2,4,6 benzene $\mathrm{b}^{\mathrm{b}}$ & 1.90 & $1.91(-0.5)$ & $1.90(0.0)$ \\
\hline FADNAN & $\mathrm{C}_{6} \mathrm{H}_{3} \mathrm{~N}_{3} \mathrm{O}_{4} \mathrm{~F}_{2}$ & $\left(\mathrm{~N}, \mathrm{~N}-\mathrm{D}\right.$ ifluoroamino)dinitro-2,4 benzene ${ }^{\mathrm{b}}$ & 1.76 & $1.80(-2.3)$ & $1.80(-2.3)$ \\
\hline TNBENZ & $\mathrm{C}_{8} \mathrm{H}_{3} \mathrm{~N}_{3} \mathrm{O}_{6}$ & TNB 1,3,5-Trinitrobenzene & 1.68 & $1.75(-4.2)$ & $1.75(-4.2)$ \\
\hline $\mathrm{PIC}-$ & $\mathrm{C}_{6} \mathrm{H}_{3} \mathrm{~N}_{3} \mathrm{O}_{7}$ & PIC ACID Picric acid 2,4,6 trinitrophenol & 1.77 & $1.83(-3.4)$ & $1.83(-3.4)$ \\
\hline TNITAN & $\mathrm{C}_{8} \mathrm{H}_{3} \mathrm{~N}_{5} \mathrm{O}_{8}$ & TENA $2,3,4,6$ Tetranitroaniline ${ }^{b}$ & 1.87 & $1.87(0.0)$ & $1.87(0.0)$ \\
\hline DNBENZ & $\mathrm{C}_{6} \mathrm{H}_{4} \mathrm{~N}_{2} \mathrm{O}_{4}$ & DNB m-Dinitrobenzene & 1.58 & $1.60(-1.3)$ & $1.60(-1.3)$ \\
\hline DNITBZ & $\mathrm{C}_{8} \mathrm{H}_{4} \mathrm{~N}_{2} \mathrm{O}_{4}$ & $\mathrm{p}$-Dinitrobenzene & 1.62 & $1.60(1.2)$ & $1.60(1.2)$ \\
\hline DNOPHL & $\mathrm{C}_{8} \mathrm{H}_{4} \mathrm{~N}_{2} \mathrm{O}_{5}$ & 2,4 -Dinitrophenol ${ }^{b}$ & 1.67 & $1.71(-2.4)$ & $1.70(-1.8)$ \\
\hline DNPHOL & $\mathrm{C}_{8} \mathrm{H}_{4} \mathrm{~N}_{2} \mathrm{O}_{5}$ & 2,6-Dinitrophenol ${ }^{b}$ & 1.70 & $1.71(-0.6)$ & $1.70(0.0)$ \\
\hline TNIOAN & $\mathrm{C}_{6} \mathrm{H}_{4} \mathrm{~N}_{4} \mathrm{O}_{6}$ & TNA $2,4,6$ Trinitroaniline $b$ & 1.76 & $1.76(0.0)$ & $1.77(-0.8)$ \\
\hline NITRBE & $\mathrm{C}_{6} \mathrm{H}_{5} \mathrm{NO}_{2}$ & Nitrobenzene & 1.37 & $1.40(-2.2)$ & $1.39(-1.5)$ \\
\hline ONP- & $\mathrm{C}_{8} \mathrm{H}_{5} \mathrm{NO}_{3}$ & o-Nitrophenol & 1.49 & $1.53(-2.7)$ & $1.52(-2.0)$ \\
\hline MNPHOL & $\mathrm{C}_{8} \mathrm{H}_{5} \mathrm{NO}_{3}$ & $\mathrm{~m}$-Nitrophenol ${ }^{\mathrm{b}}$ & 1.48 & $1.53(-3.4)$ & $1.52(-2.7)$ \\
\hline DATNBZ & $\mathrm{C}_{6} \mathrm{H}_{5} \mathrm{~N}_{8} \mathrm{O}_{6}$ & DATB Diamino trinitrobenzene ${ }^{b}$ & 1.84 & $1.78(3.3)$ & $1.78(3.3)$ \\
\hline MNIANL & $\mathrm{C}_{6} \mathrm{H}_{6} \mathrm{~N}_{2} \mathrm{O}_{2}$ & $m$-Nitroaniline $e^{b}$ & 1.44 & $1.45(-0.7)$ & $1.45(-0.7)$ \\
\hline NANILI & $\mathrm{C}_{8} \mathrm{H}_{6} \mathrm{~N}_{2} \mathrm{O}_{2}$ & 4-Nitroaniline & 1.43 & $1.45(-1.4)$ & $1.45(-1.4)$ \\
\hline TATNBZ & $\mathrm{C}_{8} \mathrm{H}_{8} \mathrm{~N}_{6} \mathrm{O}_{3}$ & TATB 1,3,5-Triamino-2,4,6-trinitrobenzene & 1.94 & $1.79(7.7)$ & $1.80(7.2)$ \\
\hline DNPIMZ & $\mathrm{C}_{6} \mathrm{H}_{6} \mathrm{~N}_{4} \mathrm{O}_{4}$ & 1,4-Dinitro-2-isopropylimidazole ${ }^{b}$ & 1.43 & $1.50(-4.9)$ & $1.50(-4.9)$ \\
\hline TNT- & $\mathrm{C}_{7} \mathrm{H}_{5} \mathrm{~N}_{3} \mathrm{O}_{8}$ & TNT 2,4,6-Trinitrotoluene & 1.67 & $1.67(0.0)$ & $1.66(0.6)$ \\
\hline MTNANL & $\mathrm{C}_{7} \mathrm{H}_{5} \mathrm{~N}_{5} \mathrm{O}_{8}$ & TETRYL Trinitro-2,4,6-pheny Imethy Initramine $b$ & 1.73 & $1.76(-1.7)$ & $1.75(-1.2)$ \\
\hline NITOLU & $\mathrm{C}_{7} \mathrm{H}_{7} \mathrm{NO}_{2}$ & p-Nitrotoluene & 1.29 & $1.34(-3.9)$ & $1.33(-3.1)$ \\
\hline FENOAN & $\mathrm{C}_{8} \mathrm{H}_{4} \mathrm{~N}_{3} \mathrm{O}_{8} \mathrm{~F}_{3}$ & $\mathrm{~N}(\beta, \beta, \beta-\operatorname{Tr}$ ifluoroethy $\mathrm{l})-\mathrm{N}, 2,4,6$-tetranitroaniline ${ }^{\mathrm{b}}$ & 1.79 & $1.86(-3.9)$ & $1.86(-3.9)$ \\
\hline EITNB- & $\mathrm{C}_{8} \mathrm{H}_{8} \mathrm{~N}_{8} \mathrm{O}_{6}$ & 1-Ethy leneimino-2,4,6-trinitrobenzene & 1.63 & $1.67(-2.5)$ & $1.68(-3.1)$ \\
\hline TNOXYL & $\mathrm{C}_{8} \mathrm{H}_{7} \mathrm{~N}_{3} \mathrm{O}_{8}$ & TNX 2,4,6-Trinitro-m-xylene ${ }^{b}$ & 1.63 & $1.60(1.8)$ & $1.60(1.8)$ \\
\hline TNPHNT & $\mathrm{C}_{8} \mathrm{H}_{7} \mathrm{~N}_{3} \mathrm{O}_{7}$ & $2,4,6$-Trinitropheneto $\mathrm{l}^{\mathrm{b}}$ & 1.56 & $1.62(-3.8)$ & $1.62(-3.8)$ \\
\hline ANTZCO & $\mathrm{C}_{8} \mathrm{H}_{14} \mathrm{~N}_{8} \mathrm{O}_{8}$ & 1,5-Diacety $1-3,7$-dinitro-tetraazacyclooctane ${ }^{b}$ & 1.63 & $1.49(8.6)$ & $1.50(8.0)$ \\
\hline TNONAP & $\mathrm{C}_{10} \mathrm{H}_{4} \mathrm{~N}_{4} \mathrm{O}_{6}$ & $1,4,5,8-$ Tetranitronaph thalene $^{b}$ & 1.82 & $1.76(3.3)$ & $1.76(3.3)$ \\
\hline FBATNB & $\mathrm{C}_{10} \mathrm{H}_{1:} \mathrm{O}_{6} \mathrm{~N}_{4} \mathrm{~F}$ & $\mathrm{~N}$-Fluoro,N-t-butyl)-1-amino trinitrobenzene ${ }^{b}$ & 1.54 & $1.55(-0.6)$ & $1.54(0.0)$ \\
\hline HNI ABZ & $\mathrm{C}_{12} \mathrm{H}_{4} \mathrm{~N}_{8} \mathrm{O}_{12}$ & HNAB $2,2^{\prime}, 4,4^{\prime}, 6,6^{\prime}-$ Hexanitroazobenzene ${ }^{b}$ & 1.80 & $1.79(0.6)$ & $1.80(0.0)$ \\
\hline DNTDPH & $\mathrm{C}_{12} \mathrm{H}_{8} \mathrm{~N}_{2} \mathrm{O}_{4}$ & $4,4^{\prime}-$ Dinitrodipheny 1 & 1.45 & $1.47(-1.4)$ & $1.46(-0.7)$ \\
\hline DNBZPY & $\mathrm{C}_{12} \mathrm{H}_{9} \mathrm{~N}_{3} \mathrm{O}_{4}$ & $2-\left(2^{\prime}, 4^{\prime}-\right.$ Dinitrobenzy l)pyridine $e^{b}$ & 1.46 & $1.46(0.0)$ & $1.46(0.0)$ \\
\hline NI AMBP & $\mathrm{C}_{12} \mathrm{H}_{10} \mathrm{~N}_{2} \mathrm{O}_{2}$ & $2^{\prime}$-Nitro-4-aminobipheny $\mathrm{l}^{\mathrm{b}}$ & 1.32 & $1.37(-3.8)$ & $1.36(-3.0)$ \\
\hline
\end{tabular}


TABLE V. (cont)

\begin{tabular}{|c|c|c|c|c|c|}
\hline \multirow[b]{2}{*}{ REFCODE } & \multirow[b]{2}{*}{ Formula } & \multirow[b]{2}{*}{ Compound Name } & \multirow{2}{*}{$\begin{array}{l}\text { Observed } \\
\text { Density } \\
\left(\mathrm{g} / \mathrm{cm}^{3}\right)\end{array}$} & \multicolumn{2}{|c|}{ Calculated Density } \\
\hline & & & & $\begin{array}{c}\text { Linear } \\
\left(\mathrm{g} / \mathrm{cm}^{3}\right)\end{array}$ & $\begin{array}{c}\text { Nonlinear } \\
\left(\mathrm{g} / \mathrm{cm}^{3}\right)\end{array}$ \\
\hline NDZABZ & $\mathrm{C}_{12} \mathrm{H}_{10} \mathrm{~N}_{4} \mathrm{O}_{2}$ & p-Nitrodiazoaminobenzene ${ }^{b}$ & 1.38 & $1.38(0.0)$ & $1.38(0.0)$ \\
\hline TACTAZ & $\mathrm{C}_{12} \mathrm{H}_{20} \mathrm{~N}_{4} \mathrm{O}_{4}$ & TAT Tetraceto-tetrazacyclo-octane $e^{b}$ & 1.40 & $1.28(8.6)$ & $1.29(7.8)$ \\
\hline MPICIN & $\mathrm{C}_{15} \mathrm{H}_{11} \mathrm{~N}_{5} \mathrm{O}_{6}$. & 1-Methyl-2-picryliminoindoline $e^{b}$ & 1.52 & $1.55(-2.0)$ & $1.55(-2.0)$ \\
\hline TDNPB- & $\mathrm{C}_{24} \mathrm{H}_{32} \mathrm{~N}_{8} \mathrm{O}_{15}$ & 1,2,3-Tris(2,4-dinitrophenoxy)benzene & 1.62 & $1.64(-1.2)$ & $1.65(-1.9)$ \\
\hline
\end{tabular}

apercent relative density errors are given in parentheses where it is defined by Rel. Err. $=100\left(\rho^{\text {obs }}-\rho^{\text {calc }}\right) / \rho^{\text {obs }}$.

${ }^{b}$ Compounds that are also members of the basis set.

References: NTRGUA, J. H. Bryden, L. A. Burkardt, E. W. Hughes, and J. Donohue, Acta Cryst. 9, 573 (1956); DMN-, B. Krebs, J. Mandt, R. E. Cobbledick, and R. W. H. Small, Acta Cryst. B35, 402 (1979); DNEDAM, J. W. Turley, Acta Cryst. B24, 942 (1968); NIPYAZ, C. Tarimci and E. Schempp, Acta Cryst. B33, 240 (1977); MENFXN, A. F. Careron and A. A. Freer, Acta Cryst. B30, 354 (1974); CTMTNA, C. S. Choi and E. Prince, Acta Cryst. B28, 2857 (1972); AMPYRM, J. Scheinbeim and E. Schempp, Acta Cryst. B32, 607 (1976); DINA- J. Halfpenny and R. W. H. Small, Acta Cryst. B34, 3452 (1978); OCHTET, C. S. Choi and H. P. Boutin, Acta Cryst. B26, 1235 (1970); DNITPY, R. Destro, T. Pilati, and M. Simonetta, Acta Cryst. B30, 2071 (1974); AMNTPY, R. Destro, T. Pilati, and M. Simonetta, Acta Cryst. B31, 2883 (1975); AMPYRD, M. Chao, E. Schempp, and R. D. Rosenstein, Acta Cryst. B31, 2922 (1975); AMIPYR, M. Chao, E. Schempp, and R. D. Rosenstein, Acta Cryst. B31, 2924 (1975); AMPYRE, M. Chao and E. Schempp, Acta Cryst. B33, 1557 (1977); PERYTN, H. H. Cady and A. C. Larson, Acta Cryst. B31, 1864 (1975); DNPMTA, C. S. Choi and S. Bulusu, Acta Cryst. B30, 1576 (1974); HNOBEN, Z. A. Akopyan, Yu. T. Struchkov, and V. G. Dashevskii, Z. Struct. Khim. 7, 408 (1966); DNBZFX, C. K. Prout, O. J. R. Hodder, and D. Viterbo, Acta Cryst. B28, 1523 (1972); FANTBZ, P. Batail, D. Grandjean, F. Dudragne and C. Michaud, Acta Cryst. B31, 1367 (1975); FADNAN, P. Batail, M. Louer, D. Grandjean, F. Dudragne, and C. Michaud, Acta Cryst. B32, 2780 (1976); TNBENZ, C. S. Choi and J. E. Abel, Acta Cryst. B28, 193 (1972); PIC-, E. N. Duesler, J. H. Engelmann, D. Y. Curtain, and 1. C. Paul, Cryst. Struct. Comm. 7, 449 (1978); TNITAN, C. Dickinson, J. M. Stewart and J. R. Holden, Acta Cryst. 21, 663 (1966); DNBENZ, J. Trotter and C. S. Williston, Acta Cryst. 21, 285 (1966); DNITBZ, F. Di Rienzo, A. Domenicano, and L. R. di Sanseverino, Acta Cryst. B36, 586 (1980); DNOPHL, T. Kagawa, R. Kawai, S. Kashino, and M. Haisa, Acta Cryst. B32, 317 (1976); DNPHOL, F. Iwasaki, M. Sato, and A. Aihara, Acta Cryst. B32, 102 (1976); TNIOAN, J. R. Holden, C. Dickinson, and C. M. Bock, J. Phys. Chem. 76, 3597 (1972); NITRBE, J. Trotter, Acta Cryst. 12, 884 (1959); ONP-, F. Iwasaki and Y. Kawano, Acta Cryst. B34, 1286 (1978); MNPHOL, F. Pandarese, L. Ungaretti, and A. Coda, Acta Cryst. B31, 2671 (1975); DATNBZ, J. R. Holden, Acta Cryst. 22, 545 (1967); MNIANL, A. C. Skapski and J. L. Stevenson, J. C. S. Perkin II, 1197 (1973); NANLLI, K. N. Trueblood, E. Goldish, and J. Donohue, Acta Cryst. 14, 1009 (1961); TATNBZ, H. H. Cady and A. C. Larson, Acta Cryst. 18, 485 (1965); DNPIMZ, R. S. Glass, J. F. Blount, D. Butler, A. Perrotta, and E. P. Oliveto, Can. J. Chem. 50, 3472 (1972); TNT-, C. R. Berry, M. H. van Horn, R. L. Griffith, Acta Cryst. 7, 135 (1954); MTNANL, H. H. Cady, Acta Cryst. 23, 601 (1967); NITOLU, J. V. Barve and L. M. Pant, Acta Cryst. B27, 1158 (1971); FENOAN, J. R. Holden and C. Dickinson, J. Phys. Chem. 73,1199 (1969); EITNB-, J. C. Barnes, J. Iball, and W. R. Smith, Acta Cryst. B33, 848 (1977); TNOXYL, J. H. Bryden, Acta Cryst. B28, 1395 (1972); TNPHNT, C. M. Gramacciol, R. Destro, and M. Simonetta, Acta Cryst. B24, 129 (1968); ANTZCO, A. Santoro, C. S. Choi, and J. E. Abel, Acta Cryst. B31, 2126 (1975); TNONAP, J. R. Holden and C. Dickinson, J. C. S. (D) Chem. Commun. 144 (1969); FBATNB, P. Batail, D. Grandjean, F. Dudragne, and C. Michaud, Acta Cryst. B30, 2653 (1974); HNIABZ, E. J. Graeber and B. Morosin, Acta Cryst. B30, 310 (1974); DNTDPH, E. G. Boonstra, Acta Cryst. 16, 816 (1963); DNBZPY, K. Seff and K. N. Trueblood, Acta Cryst. B24, 1406 (1968); NIAMBP, L. Fallon and H. L. Ammon, J. Cryst. Mol. Struct. 4, 63 (1974); NDZABZ, Yu. D. Kondrashev, Z. Strukt. Khim. 15, 517 (1974); TACTAZ, C. S. Choi, J. E. Abel, B. Dickens, and J. M. Stewart, Acta Cryst. B29, 651 (1973); MPICIN, A. S. Bailey, W. A. Warr, G. B. Allison, and C. K. Prout, J. C. S. (C), 956 (1970); TDNPB-, V. Cody, J. P. Hazel, and P. A. Lehmann, Acta Cryst. B34, 3449 (1978). 
TABLE VI. Comparison of the Observed Densities with the Linear and Nonlinear Least-Squares S34-Calculated Densities for Explosives Compounds Prepared at Los Alamos

\begin{tabular}{|c|c|c|c|c|}
\hline \multirow[b]{2}{*}{ Formula } & \multirow[b]{2}{*}{ Compound name } & \multirow{2}{*}{$\begin{array}{c}\text { Observed } \\
\text { Density } \\
\left(\mathrm{g} / \mathrm{cm}^{3}\right) \\
\end{array}$} & \multicolumn{2}{|c|}{ Calculated Density } \\
\hline & & & $\begin{array}{l}\text { Linear } \\
\left(\mathrm{g} / \mathrm{cm}^{3}\right)\end{array}$ & $\begin{array}{c}\text { Nonlinear } \\
\left(\mathrm{g} / \mathrm{cm}^{3}\right)\end{array}$ \\
\hline $\mathrm{C}_{2} \mathrm{H}_{2} \mathrm{~N}_{4} \mathrm{O}_{2}$ & 4-Nitro-1,2,3-triazole & 1.72 & $1.77(-2.9)^{\mathrm{a}}$ & $1.75(-1.7)$ \\
\hline $\mathrm{C}_{3} \mathrm{H}_{2} \mathrm{~N}_{4} \mathrm{O}_{4}$ & 2,4-Dinitroimidazole & 1.76 & $1.82(-3.4)$ & $1.82(-3.4)$ \\
\hline $\mathrm{C}_{4} \mathrm{~N}_{8} \mathrm{O}_{8}$ & $4,4^{\prime}$-Dinitro-3,3-bif urazany 1 & 1.85 & $1.92(-3.8)$ & $1.92(-3.8)$ \\
\hline $\mathrm{C}_{4} \mathrm{H}_{2} \mathrm{~N}_{8} \mathrm{O}_{4}$ & $5,5^{\prime}$-Dinitro-3,3'-bi-1,2,4-triazole & 1.76 & $1.85(-5.1)$ & $1.85(-5.1)$ \\
\hline $\mathrm{C}_{4} \mathrm{H}_{5} \mathrm{~N}_{8} \mathrm{O}_{4}$ & 4-Amino-3,5-dinitro-1-methylpyrazole & 1.70 & $1.69(0.6)$ & $1.69(0.6)$ \\
\hline $\mathrm{C}_{5} \mathrm{H}_{6} \mathrm{~N}_{8} \mathrm{O}_{4}$ & 3,5-Dinitro-2,4,6-triaminopyridine & 1.88 & $1.75(6.9)$ & $1.76(6.4)$ \\
\hline $\mathrm{C}_{6} \mathrm{H}_{2} \mathrm{~N}_{4} \mathrm{O}_{8}$ & $1,2,4,5-$ Tetranitrobenzene & 1.82 & $1.86(-2.2)$ & $1.86(-2.2)$ \\
\hline $\mathrm{C}_{6} \mathrm{H}_{2} \mathrm{~N}_{8} \mathrm{O}_{10}$ & Pentanitroaniline & 1.77 & $1.95(-10.2)$ & $1.85(-10.2)$ \\
\hline $\mathrm{C}_{7} \mathrm{H}_{4} \mathrm{~N}_{8} \mathrm{O}_{6}$ & 5-Picrylaminotetrazole & 1.91 & $1.80(5.8)$ & $1.79(6.3)$ \\
\hline $\mathrm{C}_{8} \mathrm{H}_{3} \mathrm{~N}_{7} \mathrm{O}_{8}$ & 4-Nitro-1-picryl-1,2,3-triazole & 1.85 & $1.82(1.6)$ & $1.82(1.6)$ \\
\hline $\mathrm{C}_{8} \mathrm{H}_{3} \mathrm{~N} \mathrm{O}_{8}$ & 4-Nitro-2-picryl-1,2,3-iriazole & 1.75 & $1.82(-4.0)$ & $1.82(-4.0)$ \\
\hline $\mathrm{C}_{8} \mathrm{H}_{3} \mathrm{~N}_{7} \mathrm{O}_{8}$ & 3-Nitro-1-picryl-1,2,4-triazole & 1.75 & $1.82(-4.0)$ & $1.82(-4.0)$ \\
\hline $\mathrm{C}_{8} \mathrm{H}_{3} \mathrm{~N}_{7} \mathrm{O}_{2}$ & 3-Nitro-4-picrylaminofurazan & 1.81 & $1.84(-1.7)$ & $1.84(-1.7)$ \\
\hline $\mathrm{C}_{6} \mathrm{H}_{4} \mathrm{~N}_{8} \mathrm{O}_{6}$ & 1-(3,4-Dinitropheny 1$)-4$-nitro-1,2,3-triazole & 1.73 & $1.73(0.0)$ & $173(0.0)$ \\
\hline $\mathrm{C}_{8} \mathrm{H}_{4} \mathrm{~N}_{8} \mathrm{O}_{6}$ & $1-(3,5-D i n i t r o p h e n y 1)-4-$ nitro-1,2,3-triazole & 1.74 & $1.73(0.6)$ & $1.73(0.6)$ \\
\hline $\mathrm{C}_{8} \mathrm{H}_{4} \mathrm{~N}_{6} \mathrm{O}_{8}$ & 1-Picryl-1,2,4-triazole & 1.70 & $1.74(-2.4)$ & $1.74(-2.4)$ \\
\hline $\mathrm{C}_{8} \mathrm{H}_{4} \mathrm{~N}_{6} \mathrm{O}_{6}$ & 2-Picryl-1,2,3-triazole & 1.69 & $1.74(-3.0)$ & $1.74(-3.0)$ \\
\hline $\mathrm{C}_{8} \mathrm{H}_{4} \mathrm{~N}_{8} \mathrm{O}_{6}$ & $1-$ Picryl-1,2,3-triazole & 1.70 & $1.74(-2.7)$ & $1.74(-2.7)$ \\
\hline $\mathrm{C}_{6} \mathrm{H}_{4} \mathrm{~N}_{6} \mathrm{O}_{7}$ & 2-Picrylamino-1,3,4-oxadiazole & 1.76 & $1.77(-0.6)$ & $1.77(-0.8)$ \\
\hline $\mathrm{C}_{8} \mathrm{H}_{5} \mathrm{~N}_{2} \mathrm{O}_{8}$ & 1-(3-Amino-2,4,6-trinitropheny 1$)-1,2,3$-triazole & 1.75 & $1.75(0.0)$ & $1.75(0.0)$ \\
\hline $\mathrm{C}_{6} \mathrm{H}_{5} \mathrm{~N}_{7} \mathrm{O}_{6}$ & 4-Picrylamino-1,2,4-triazole & 1.78 & $1.74(2.2)$ & $1.74(2.2)$ \\
\hline $\mathrm{C}_{8} \mathrm{H}_{5} \mathrm{~N}_{2} \mathrm{O}_{8}$ & 4-Picrylamino-1,2,3-triazole & 1.78 & $1.74(2.2)$ & $1.74(2.2)$ \\
\hline $\mathrm{C}_{8} \mathrm{H}_{3} \mathrm{~N}_{7} \mathrm{O}_{7}$ & 3-Amino-4-picrylaminofurazan & 1.77 & $1.77(0.0)$ & $1.77(0.0)$ \\
\hline $\mathrm{C}_{8} \mathrm{H}_{5} \mathrm{~N}_{8} \mathrm{O}_{6}$ & 3-Amino-6-picrylamino-s-tetrazine & 1.78 & $1.77(0.6)$ & $1.78(0.0)$ \\
\hline $\mathrm{C}_{8} \mathrm{H}_{8} \mathrm{~N}_{8} \mathrm{O}_{8}$ & 3-Amino-5-picrylamino-1,2,4-triazole & 1.85 & $1.75(5.4)$ & $1.75(5.4)$ \\
\hline $\mathrm{C}_{6} \mathrm{H}_{6} \mathrm{~N}_{8} \mathrm{O}_{8}$ & 1, $1^{\prime}$-Dimethy $1-3,3^{\prime}, 5,5^{\prime}$-tetranitro-4,4'-bipyrazolyl & 1.75 & $1.73(1.1)$ & $1.73(1.1)$ \\
\hline $\mathrm{C}_{9} \mathrm{H}_{3} \mathrm{~N}_{7} \mathrm{O}_{10}$ & 2,4 -Dinitro-1-picrylimidazole & 1.75 & $1.83(-4.6)$ & $1.84(-5.1)$ \\
\hline $\mathrm{C}_{9} \mathrm{H}_{4} \mathrm{~N}_{8} \mathrm{O}_{8}$ & 2-Nitro-1-picrylimidazole & 1.75 & $1.77(-1.1)$ & $1.77(-1.1)$ \\
\hline $\mathrm{C}_{8} \mathrm{H}_{4} \mathrm{~N}_{8} \mathrm{O}_{8}$ & 4-Nitro-1-picrylimidazole & 1.75 & $1.77(-1.1)$ & $1.77(-1.1)$ \\
\hline $\mathrm{C}_{8} \mathrm{H}_{4} \mathrm{~N}_{8} \mathrm{O}_{8}$ & 4-Nitro-1-picrylpyrazole & 1.70 & $1.77(-4.1)$ & $1.77(-4.1)$ \\
\hline $\mathrm{C}_{8} \mathrm{H}_{5} \mathrm{~N}_{5} \mathrm{O}_{6}$ & 1-Picry limidazole & 1.75 & $1.69(3.4)$ & $1.69(3.4)$ \\
\hline $\mathrm{C}_{8} \mathrm{H}_{5} \mathrm{~N}_{8} \mathrm{O}_{6}$ & 1-Picrylpyrazole & 1.60 & $1.69(-5.6)$ & $1.69(-5.6)$ \\
\hline $\mathrm{C}_{8} \mathrm{H}_{8} \mathrm{~N}_{7} \mathrm{O}_{8}$ & 4-Nitro-3-picry laminopyrazole & 1.77 & $1.77(0.0)$ & $1.78(-0.6)$ \\
\hline $\mathrm{C}_{9} \mathrm{H}_{6} \mathrm{~N}_{8} \mathrm{O}_{6}$ & 4-Picry laminopyrazole & 1.70 & $1.69(0.6)$ & $1.70(0.0)$ \\
\hline $\mathrm{C}_{9} \mathrm{H}_{8} \mathrm{~N}_{6} \mathrm{O}_{6}$ & 3-Picry laminopyrazole & 1.70 & $1.69(0.6)$ & $1.70(0.0)$ \\
\hline $\mathrm{C}_{8} \mathrm{H}_{7} \mathrm{~N}_{3} \mathrm{O}_{11}$ & $2-(2,2$-Dinitropropoxy)-1,3,5-trinitrobenzene & 1.69 & $1.72(-1.8)$ & $1.72(-1.8)$ \\
\hline $\mathrm{C}_{9} \mathrm{H}_{9} \mathrm{~N}_{8} \mathrm{O}_{12}$ & 1,3,5-Trinitro-2,4,6-tris(methy lnitramino)benzene & 1.65 & $1.77(-7.3)$ & $1.76(-6.7)$ \\
\hline $\mathrm{C}_{10} \mathrm{H}_{3} \mathrm{~N}_{80} \mathrm{O}_{10}$ & 4-Nitro-4'-picrylamino-3,3-bifurazany l & 1.77 & $1.83(-3.4)$ & $1.84(-4.0)$ \\
\hline $\mathrm{C}_{10} \mathrm{H}_{4} \mathrm{~N}_{8} \mathrm{O}_{8}$ & $3,3^{\prime}, 5,5^{\prime}$-Tetranitro-2,2'-azopyridine & 1.83 & $1.74(4.9)$ & $1.75(4.4)$ \\
\hline $\mathrm{C}_{10} \mathrm{H}_{5} \mathrm{~N}_{7} \mathrm{O}_{10}$ & 3,5-Dinitro-1-methy 1-4-picrylpyrazole & 1.72 & $1.77(-2.9)$ & $1.77(-2.9)$ \\
\hline $\mathrm{C}_{10} \mathrm{H}_{8} \mathrm{~N}_{8} \mathrm{O}_{8}$ & 2-Picry laminopyrimidine & 1.71 & $1.67(2.3)$ & $1.67(2.3)$ \\
\hline $\mathrm{C}_{10} \mathrm{H}_{8} \mathrm{~N}_{6} \mathrm{O}_{8}$ & 1-Methyl-3-nitro-4-picrylpyrazole & 1.71 & $1.70(0.6)$ & $1.71(0.0)$ \\
\hline $\mathrm{C}_{10} \mathrm{H}_{6} \mathrm{~N}_{8} \mathrm{O}_{10}$ & 3,5-Dinitro-1-methy 1-4-picry laminopyrazole & 1.74 & $1.77(-1.7)$ & $1.77(-1.7)$ \\
\hline $\mathrm{C}_{12} \mathrm{H}_{4} \mathrm{~N}_{8} \mathrm{O}_{10}$ & 4,6-Dinitro-1-picrylbenzotriazole & 1.86 & $1.80(3.2)$ & $1.80(3.2)$ \\
\hline $\mathrm{C}_{12} \mathrm{H}_{4} \mathrm{~N}_{8} \mathrm{O}_{10}$ & 5.7-Dinitro-1-picrylbenzotriazole & 1.74 & $1.80(-3.4)$ & $1.80(-3.4)$ \\
\hline $\mathrm{C}_{12} \mathrm{H}_{4} \mathrm{~N}_{8} \mathrm{O}_{10}$ & 5,6 -Dinitro-1-picrylbenzotriazole & 1.77 & $1.80(-1.7)$ & $1.80(-1.7)$ \\
\hline $\mathrm{C}_{12} \mathrm{H}_{13} \mathrm{~N}_{7} \mathrm{O}_{18}$ & 1,3 bis(2,2-Dinitropropoxy)-2,4,6-trinitrobenzene & 1.67 & $1.71(-2.4)$ & $1.71(-2.4)$ \\
\hline $\mathrm{C}_{14} \mathrm{H}_{8} \mathrm{~N}_{10} \mathrm{O}_{12}$ & 1-Picryl-4-picry lamino-1,2,3-triazole & 1.75 & $1.79(-2.3)$ & $1.79(-2.3)$ \\
\hline $\mathrm{C}_{14} \mathrm{H}_{6} \mathrm{~N}_{10} \mathrm{O}_{12}$ & 2-Picry 1-3-picrylamino-1,2,4-triazole & 1.80 & $1.79(0.6)$ & $1.79(0.6)$ \\
\hline $\mathrm{C}_{14} \mathrm{H}_{8} \mathrm{~N}_{10} \mathrm{O}_{13}$ & 3,5 -bis(Picrylamino)-1,2,4-oxadiazole & 1.70 & $1.80(-5.9)$ & $1.81(-6.5)$ \\
\hline
\end{tabular}


TABLE VI. (cont)

\begin{tabular}{|c|c|c|c|c|}
\hline \multirow[b]{2}{*}{ Formula } & \multirow[b]{2}{*}{ Compound name } & \multirow{2}{*}{$\begin{array}{c}\text { Observed } \\
\text { Density } \\
\left(\mathrm{g} / \mathrm{cm}^{3}\right)\end{array}$} & \multicolumn{2}{|c|}{ Calculated Density } \\
\hline & & & $\begin{array}{c}\text { Linear } \\
\left(\mathrm{g} / \mathrm{cm}^{3}\right)\end{array}$ & $\begin{array}{l}\text { Nonlinear } \\
\left(\mathrm{g} / \mathrm{cm}^{3}\right)\end{array}$ \\
\hline $\mathrm{C}_{14} \mathrm{H}_{6} \mathrm{~N}_{10} \mathrm{U}_{13}$ & 3,4 -bis(Picry lamino)f urazan & 1.86 & $1.80(3.2)$ & $1.81(2.7)$ \\
\hline $\mathrm{C}_{14} \mathrm{H}_{7} \mathrm{~N}_{11} \mathrm{O}_{12}$ & 3,5-bis(Picry lamino)-1,2,4-triazole & 1.81 & $1.79(1.1)$ & $1.79(1.1)$ \\
\hline $\mathrm{C}_{14} \mathrm{H}_{6} \mathrm{~N}_{12} \mathrm{O}_{12}$ & 3,6-bis(Picry lamino)-s-tetrazine & 1.82 & $1.80(1.1)$ & $1.81(0.5)$ \\
\hline $\mathrm{C}_{15} \mathrm{H}_{8} \mathrm{~N}_{8} \mathrm{O}_{12}$ & 1,4-Dipicry lpyrazole & 1.71 & $1.76(-2.9)$ & $1.76(-2.2)$ \\
\hline $\mathrm{C}_{15} \mathrm{H}_{8} \mathrm{~N}_{10} \mathrm{O}_{14}$ & 4-Nitro-1-picryl-3-picry laminopyrazole & 1.72 & $1.80(-4.7)$ & $1.81(-5.2)$ \\
\hline $\mathrm{C}_{18} \mathrm{H}_{6} \mathrm{~N}_{10} \mathrm{O}_{14}$ & 5-Nitro-1-picryl-4-picry laminopyrazole & 1.72 & $1.80(-4.7)$ & $1.81(-5.2)$ \\
\hline $\mathrm{C}_{15} \mathrm{H}_{7} \mathrm{~N}_{9} \mathrm{O}_{12}$ & 1-Picryl-5-picry laminopyrazole & 1.67 & $1.75(-4.8)$ & $1.76(-5.4)$ \\
\hline $\mathrm{C}_{15} \mathrm{H}_{7} \mathrm{~N}_{9} \mathrm{O}_{12}$ & 1-Picryl-4-picry laminopyrazole & 1.73 & $1.75(-1.2)$ & $1.76(-1.7)$ \\
\hline $\mathrm{C}_{15} \mathrm{H}_{7} \mathrm{~N}_{2} \mathrm{O}_{12}$ & 1-Picry 1-3-picrylaminopyrazole & 1.67 & $1.75(-4.8)$ & $1.76(-5.4)$ \\
\hline $\mathrm{C}_{15} \mathrm{H}_{8} \mathrm{~N}_{10} \mathrm{O}_{12}$ & 3,5-bis(Picrylamino)pyrazole & 1.70 & $1.76(-3.5)$ & $1.76(-3.5)$ \\
\hline $\mathrm{C}_{20} \mathrm{H}_{6} \mathrm{~N}_{22} \mathrm{O}_{14}$ & $4,4^{\prime}-$ bis(Picry lamino $)-3,3^{\prime}$-bif urazany 1 & 1.81 & $1.80(0.6)$ & $1.81(0.0)$ \\
\hline $\mathrm{C}_{16} \mathrm{H}_{7} \mathrm{~N}_{2} \mathrm{O}_{12}$ & 1-Picryl-2-picry limino-1,2-dihydropyrimidine & 1.74 & $1.73(0.6)$ & $1.24(0.0)$ \\
\hline $\mathrm{C}_{10} \mathrm{H}_{9} \mathrm{~N}_{14} \mathrm{O}_{22}$ & $5,5^{\prime}-$ bis(Picry lamino) $-3,3^{\prime}-b i-1,2,4-t r i a z o l y l$ & 1.80 & $1.78(1.1)$ & $1.78(1.1)$ \\
\hline $\mathrm{C}_{17} \mathrm{H}_{8} \mathrm{~N}_{23} \mathrm{O}_{10}$ & 2,6-bis(Picry lazo)-3,5-dinitropyridine & 1.86 & $1.79(3.8)$ & $1.81(2.7)$ \\
\hline $\mathrm{C}_{17} \mathrm{H}_{7} \mathrm{~N}_{11} \mathrm{O}_{16}$ & 2,6-bis(Picry lamino)-3,5-dinitropyridine & 1.75 & $1.81(-3.4)$ & $1.81(-3.4)$ \\
\hline $\mathrm{C}_{17} \mathrm{H}_{7} \mathrm{~N}_{11} \mathrm{O}_{10}$ & 2,5-bis(Picrylamino)-3,6-dinitropyridine & 1.77 & $1.81(-2.3)$ & $1.81(-2.3)$ \\
\hline $\mathrm{C}_{17} \mathrm{H}_{7} \mathrm{~N}_{11} \mathrm{O}_{16}$ & 3,5-bis(Picrylamino)-2,6-dinitropyridine & 1.77 & $1.81(-2.3)$ & $1.81(-2.3)$ \\
\hline $\mathrm{C}_{80} \mathrm{H}_{4} \mathrm{~N}_{12} \mathrm{O}_{14}$ & 2,6-Dipicry lbenzo[ $\left.1,2-\mathrm{d}: 4,5-\mathrm{d}^{\prime}\right]$ b istriazole-4,8-dione & he 1.85 & $1.83(1.1)$ & $1.84(0.5)$ \\
\hline $\mathrm{C}_{10} \mathrm{H}_{6} \mathrm{~N}_{12} \mathrm{O}_{12}$ & 1,5-Dipicry lbenzo[ $\left.1,2-\mathrm{d}: 4,5-\mathrm{d}^{\prime}\right] \mathrm{b}$ istriazole & 1.79 & $1.77(1.1)$ & $1.78(0.6)$ \\
\hline $\mathrm{C}_{18} \mathrm{H}_{6} \mathrm{~N}_{12} \mathrm{O}_{12}$ & 1,7-Dipicrylbenzo[ $\left.1,2-\mathrm{d}: 4,5-\mathrm{d}^{\prime}\right]$ b istr iazole & 1.80 & $1.77(1.7)$ & $1.78(1.1)$ \\
\hline $\mathrm{C}_{18} \mathrm{H}_{7} \mathrm{~N}_{11} \mathrm{O}_{18}$ & 1,3-bis(P icry lamino)-2,4,6-trinitrobenzene & 1.79 & $1.82(-1.7)$ & $1.83(-2.2)$ \\
\hline $\mathrm{C}_{18} \mathrm{H}_{8} \mathrm{~N}_{10} \mathrm{O}_{16}$ & 1,5-bis(Picrylamino)-2,4-dinitrobenzene & 1.78 & $1.78(0.0)$ & $1.79(-0.6)$ \\
\hline $\mathrm{C}_{18} \mathrm{H}_{8} \mathrm{~N}_{18} \mathrm{O}_{18}$ & 1,4-Dipicry 1-5-picrylamino-2-tetrazoline & 1.74 & $1.82(-4.6)$ & $1.83(-5.2)$ \\
\hline $\mathrm{C}_{21} \mathrm{H}_{9} \mathrm{~N}_{13} \mathrm{O}_{10}$ & 3,5-bis(Picrylamino)-1-picry lpyrazole & 1.67 & $1.78(-6.6)$ & $1.79(-7.2)$ \\
\hline $\mathrm{C}_{28} \mathrm{H}_{8} \mathrm{~N}_{15} \mathrm{O}_{18}$ & 2,4,6-tris(Picry lamino)-s-triazine & 1.75 & $1.80(-2.9)$ & $1.81(-3.4)$ \\
\hline $\mathrm{C}_{22} \mathrm{H}_{9} \mathrm{~N}_{25} \mathrm{O}_{20}$ & 5-Nitro-2,4,6-tris(picry lamino)pyrimidine & 1.88 & $1.81(3.7)$ & $1.82(3.2)$ \\
\hline $\mathrm{C}_{22} \mathrm{H}_{10} \mathrm{~N}_{14} \mathrm{O}_{18}$ & 2,4,6-tris(Picry lamino)pyrimidine & 1.90 & $1.78(6.3)$ & $1.78(8.3)$ \\
\hline $\mathrm{C}_{23} \mathrm{H}_{2} \mathrm{~N}_{15} \mathrm{O}_{22}$ & 3,5-Dinitro-2,4,6-tris(picrylamino)pyridine & 1.80 & $1.82(-1.1)$ & $1.83(-1.7)$ \\
\hline $\mathrm{C}_{24} \mathrm{H}_{9} \mathrm{~N}_{15} \mathrm{O}_{24}$ & 1,3,5-Trinitro-2,4,6-tris(picry lamino)benzene & 1.82 & $1.83(-0.5)$ & $1.84(-1.1)$ \\
\hline
\end{tabular}

a Percent relative density errors are given in parenthesis where it is defined by Rel. Err. $=100\left(\rho^{\text {obs }}-\rho^{\text {calc }}\right) / \rho^{\text {obs }}$ 
TABLE VII. Comparison of the Observed Densities with the Linear and Nonlinear LeastSquares S34-Calculated Densities for Nitroanilines and Hexanitrobenzene

\begin{tabular}{lccc}
\hline & \begin{tabular}{c} 
Observed \\
Density \\
\cline { 4 - 4 } Compound
\end{tabular} & \multicolumn{2}{c}{ Calculated Density } \\
\cline { 4 - 4 }$\left(\mathrm{g} / \mathrm{cm}^{3}\right)$ & 1.62 & $\begin{array}{c}\text { Linear } \\
\left(\mathrm{g} / \mathrm{cm}^{3}\right)\end{array}$ & $\begin{array}{c}\text { Nonlinear } \\
\left(\mathrm{g} / \mathrm{cm}^{3}\right)\end{array}$ \\
\hline 2,4-Dinitroaniline & 1.76 & 1.76 & 1.63 \\
2,4,6-Trinitroaniline & 1.87 & 1.87 & 1.77 \\
2,3,4,6-Tetranitroaniline & 1.77 & 1.95 & 1.87 \\
Pentanitroaniline & 1.99 & 2.01 & 1.95 \\
Hexanitrobenzene & & & 2.02
\end{tabular}


TABLE VIII. Comparison of the Observed Densities with the Linear and Nonlinear Least-Squares S34Calculated Densities for Explosives Compounds

\begin{tabular}{|c|c|c|c|c|c|}
\hline \multirow[b]{2}{*}{ Name } & \multirow[b]{2}{*}{ Formula } & \multirow[b]{2}{*}{ Compound Name } & \multirow{2}{*}{$\begin{array}{c}\text { Observed } \\
\text { Density } \\
\left(\mathrm{g} / \mathrm{cm}^{3}\right)\end{array}$} & \multicolumn{2}{|c|}{ Calculated Density } \\
\hline & & & & $\begin{array}{l}\text { Linear } \\
\left(\mathrm{g} / \mathrm{cm}^{3}\right)\end{array}$ & $\begin{array}{c}\text { Nonlinear } \\
\left(\mathrm{g} / \mathrm{cm}^{3}\right)\end{array}$ \\
\hline HNE & $\mathrm{C}_{2} \mathrm{~N}_{8} \mathrm{O}_{12}$ & Hexanitroethane & $1.85^{\mathrm{a}}$ & $2.06(-11.4)$ & $2.06(-11.4)$ \\
\hline CNTA & $\mathrm{C}_{3} \mathrm{~N}_{22}$ & Cyanuric triazide & $1.54^{b}$ & $1.62(-5.2)$ & $1.67(-8.4)$ \\
\hline RSALT & $\mathrm{C}_{3} \mathrm{H}_{6} \mathrm{~N}_{8} \mathrm{O}_{3}$ & Cyclotrimethylene trinitrosamine & $1.51^{\mathrm{a}}$ & $1.59(-5.4)$ & $1.63(-8.1)$ \\
\hline SORGUYL & $\mathrm{C}_{4} \mathrm{H}_{2} \mathrm{~N}_{3} \mathrm{O}_{10}$ & Tetranitroglycolurile & $2.01^{a}$ & $2.02(-0.5)$ & $2.04(-1.5)$ \\
\hline DINGU & $\mathrm{C}_{4} \mathrm{H}_{4} \mathrm{~N}_{6} \mathrm{O}_{6}$ & Dinitroglycolurile & $1.94^{\mathrm{a}}$ & $1.89(2.6)$ & $1.93(0.5)$ \\
\hline DNDMOA & $\mathrm{C}_{4} \mathrm{H}_{8} \mathrm{~N}_{4} \mathrm{O}_{6}$ & Dinitrodimethy loxamide & $1.52^{\mathrm{a}}$ & $1.65(-8.3)$ & $1.64(-7.7)$ \\
\hline ETN & $\mathrm{C}_{4} \mathrm{H}_{6} \mathrm{~N}_{4} \mathrm{O}_{12}$ & Erythrol tetranitrate & $1.6^{\mathrm{a}}$ & $1.78(-11.3)$ & $1.79(-11.9)$ \\
\hline TFNA & $\mathrm{C}_{5} \mathrm{H}_{7} \mathrm{~N}_{4} \mathrm{O}_{6} \mathrm{~F}_{3}$ & 1,1,1-Trifluoro-3,5,5-trinitro-3-azahexane & $1.69^{c}$ & $1.73(-2.4)$ & $1.73(-2.4)$ \\
\hline PETRIN & $\mathrm{C}_{8} \mathrm{H}_{9} \mathrm{~N}_{3} \mathrm{O}_{10}$ & Pentaerythritol trinitrate & $1.54^{\mathrm{b}}$ & $1.66(-7.8)$ & $1.66(-7.8)$ \\
\hline TNTAB & $\mathrm{C}_{6} \mathrm{O}_{6} \mathrm{~N}_{12}$ & Trinitro triazidobenzene & $1.81^{b}$ & $1.78(1.7)$ & $1.83(-1.1)$ \\
\hline DIAZ & $\mathrm{C}_{6} \mathrm{H}_{2} \mathrm{~N}_{4} \mathrm{O}_{5}$ & Diazodinitrophenol & $1.63^{a, b}$ & $1.73(-6.1)$ & $1.75(-7.4)$ \\
\hline TNR & $\mathrm{C}_{6} \mathrm{H}_{3} \mathrm{~N}_{3} \mathrm{O}_{8}$ & Trinitroresorcinol (styphnic acid) & $1.83^{\mathrm{a}}$ & $1.91(-4.4)$ & $1.91(-4.4)$ \\
\hline DNA & $\mathrm{C}_{6} \mathrm{H}_{5} \mathrm{~N}_{3} \mathrm{O}_{4}$ & $2,4-$ Dinitroaniline & $1.62^{\mathrm{c}}$ & $1.63(-0.6)$ & $1.63(-0.8)$ \\
\hline TNETB & $\mathrm{C}_{6} \mathrm{H}_{9} \mathrm{~N}_{6} \mathrm{O}_{14}$ & $2,2,2-$ Trinitroethy $1-4,4,4-$ trinitrobutyrate & $1.78^{\mathrm{b}}$ & $1.79(-0.6)$ & $1.80(-1.1)$ \\
\hline DNPA & $\mathrm{C}_{8} \mathrm{H}_{8} \mathrm{~N}_{2} \mathrm{O}_{8}$ & 2,2-Dinitropropyl acrylate & $1.477^{\mathrm{d}}$ & $1.48(-0.7)$ & $1.48(-0.7)$ \\
\hline MHN & $\mathrm{C}_{8} \mathrm{H}_{6} \mathrm{~N}_{8} \mathrm{O}_{16}$ & Mannitol hexanitrate & $1.73^{b}$ & $1.80(-4.0)$ & $1.81(-4.6)$ \\
\hline TMPTN & $\mathrm{C}_{6} \mathrm{H}_{11} \mathrm{~N}_{3} \mathrm{O}_{2}$ & Trimethylol-ethylmethane trinitrate & $1.5^{\mathrm{a}}$ & $1.54(-2.2)$ & $1.54(-2.2)$ \\
\hline HMTD & $\mathrm{C}_{8} \mathrm{H}_{22} \mathrm{~N}_{2} \mathrm{O}_{6}$ & Hexamethylenetriperoxide diamine & $1.57^{a}$ & $1.49(5.1)$ & $1.52(3.2)$ \\
\hline TNC & $\mathrm{C}_{7} \mathrm{H}_{5} \mathrm{~N}_{3} \mathrm{O}_{7}$ & 2,4,6-Trinitrocresol & $1.68^{\mathrm{a}}$ & $1.74(-3.6)$ & $1.74(-3.6)$ \\
\hline TNAN & $\mathrm{C}_{7} \mathrm{H}_{5} \mathrm{~N}_{3} \mathrm{O}_{7}$ & Trinitroanisol & $1.61^{\mathrm{a}}$ & $1.69(-5.0)$ & $1.69(-5.0)$ \\
\hline DNT & $\mathrm{C}_{7} \mathrm{H}_{6} \mathrm{~N}_{2} \mathrm{O}_{4}$ & Dinitrotoluene & $1.52^{\mathrm{a}, \mathrm{b}}$ & $1.53(-0.6)$ & $1.52(0.1)$ \\
\hline DNPTB & $\mathrm{C}_{7} \mathrm{H}_{9} \mathrm{~N}_{5} \mathrm{O}_{12}$ & 2,2 -Dinitropropy $1-4,4,4-$ trinitrobutyrate & $1.68^{\mathrm{b}}$ & $1.67(0.6)$ & $1.67(0.6)$ \\
\hline TNPON & $\mathrm{C}_{8} \mathrm{H}_{8} \mathrm{~N}_{4} \mathrm{O}_{10}$ & Trinitrophenoxethylnitrate & $1.68^{\mathrm{a}}$ & $1.73(-3.0)$ & $1.73(-3.0)$ \\
\hline DNPEN & $\mathrm{C}_{8} \mathrm{H}_{7} \mathrm{~N}_{3} \mathrm{O}_{8}$ & Dinitrophenoxyethy lnitrate & $1.60^{\mathrm{a}}$ & $1.63(-1.9)$ & $163(-1.9)$ \\
\hline ETET & $\mathrm{C}_{8} \mathrm{H}_{7} \mathrm{~N}_{5} \mathrm{O}_{8}$ & Ethyl tetryl & $1.63^{a}$ & $1.68(-3.1)$ & $1.68(-3.1)$ \\
\hline FIVONITE & $\mathrm{C}_{9} \mathrm{H}_{22} \mathrm{~N}_{4} \mathrm{O}_{13}$ & Tetramethylolcyclopentanone tetranitrate & $1.59^{\mathrm{a}}$ & $1.64(-3.1)$ & $1.65(-3.8)$ \\
\hline DNPF & $\mathrm{C}_{10} \mathrm{H}_{12} \mathrm{~N}_{4} \mathrm{O}_{12}$ & bis(2,2-Dinitropropy l)f umarate & $1.60^{\mathrm{b}}$ & $1.56(2.5)$ & $1.57(1.8)$ \\
\hline GTNB & $\mathrm{C}_{10} \mathrm{H}_{12} \mathrm{~N}_{8} \mathrm{O}_{10}$ & Ethylene glycol di-trinitrobutyrate & $1.63^{b}$ & $1.66(-1.8)$ & $1.66(-1.8)$ \\
\hline DNPS & $\mathrm{C}_{10} \mathrm{H}_{14} \mathrm{~N}_{4} \mathrm{O}_{12}$ & bis(2,2-Dinitropropy l)succ inate & $1.51^{\mathrm{b}}$ & $1.54(-2.0)$ & $1.54(-2.0)$ \\
\hline DPHEN & $\mathrm{C}_{10} \mathrm{H}_{10} \mathrm{~N}_{6} \mathrm{O}_{18}$ & Dipentaerythritol hexanitrate & $1.63^{\mathrm{b}}$ & $1.64(-0.6)$ & $1.65(-1.2)$ \\
\hline HNBP & $\mathrm{C}_{12} \mathrm{H}_{4} \mathrm{~N}_{6} \mathrm{O}_{12}$ & $2,2^{\prime}, 4,4^{\prime}, 6,6^{\prime}-$ Hexanitrodipheny! & $1.6^{\mathrm{a}}$ & $1.81(-13.1)$ & $1.81(-13.1)$ \\
\hline HNDPO & $\mathrm{C}_{12} \mathrm{H}_{4} \mathrm{~N}_{8} \mathrm{O}_{13}$ & $2,2^{\prime}, 4,4^{\prime}, 6,6^{\prime}$-Hexanitrodipheny lox ide & $1.70^{\mathrm{a}}$ & $1.82(-7.1)$ & $1.82(-7.1)$ \\
\hline TACOT & $\mathrm{C}_{12} \mathrm{H}_{4} \mathrm{~N}_{8} \mathrm{O}_{8}$ & Tetranitro-1,2,5,6-tetrazadibenzocyclooctatetrene & $1.85^{\mathrm{a}, \mathrm{d}}$ & $1.79(3.2)$ & $1.80(2.7)$ \\
\hline HNDP & $\mathrm{C}_{22} \mathrm{H}_{5} \mathrm{~N}_{7} \mathrm{O}_{12}$ & $2,2^{\prime}, 4,4^{\prime}, 6,6^{\prime}$-Hexanitrodipheny lamine & $1.64^{\mathrm{a}}$ & $1.80(-9.8)$ & $1.81(-10.4)$ \\
\hline DIPAM & $\mathrm{C}_{12} \mathrm{H}_{6} \mathrm{~N}_{8} \mathrm{O}_{12}$ & 3,3-Diamino-2, $2^{\prime}, 4,4^{\prime}, 6,6^{\prime}$-hexanitrobiphenyl & $1.79 \mathrm{~d}$ & $1.82(-1.7)$ & $1.83(-2.2)$ \\
\hline DNDPA & $\mathrm{C}_{22} \mathrm{H}_{9} \mathrm{~N}_{3} \mathrm{O}_{4}$ & Dinitrodipheny lamine & $1.42^{a}$ & $1.48(-4.2)$ & $1.48(-4.2)$ \\
\hline PENCO & $\mathrm{C}_{13} \mathrm{H}_{6} \mathrm{~N}_{5} \mathrm{O}_{31}$ & $2,2,4,4,6$-Pentanitrobenzophenone & $1.86^{\mathrm{c}}$ & $1.74(6.5)$ & $1.78(6.5)$ \\
\hline HNS & $\mathrm{C}_{14} \mathrm{H}_{6} \mathrm{~N}_{6} \mathrm{O}_{12}$ & $2,2^{\prime}, 4,4^{\prime}, 6,6^{\circ}-$ Hexanitrostilbene & $1.74^{a, d}$ & $1.73(0.6)$ & $1.74(0.0)$ \\
\hline TPEON & $\mathrm{C}_{15} \mathrm{H}_{24} \mathrm{~N}_{8} \mathrm{O}_{23}$ & Tripentaerythritol octanitrate & $1.58 \mathrm{~b}$ & $1.61(-1.9)$ & $1.62(-2.5)$ \\
\hline NONA & $\mathrm{C}_{20} \mathrm{H}_{5} \mathrm{~N}_{8} \mathrm{O}_{10}$ & $2,2^{\prime}, 2^{\prime \prime}, 4,4^{\circ}, 4^{\prime \prime}, 6,6^{\prime}, 6^{\prime \prime}$-Nonanitroterphenyl & $1.78^{c}$ & $1.83(-2.8)$ & $1.83(-2.8)$ \\
\hline ONT & $\mathrm{C}_{16} \mathrm{H}_{8} \mathrm{~N}_{8} \mathrm{O}_{18}$ & $2,2^{\prime}, 4,4^{\prime}, 4^{\prime \prime}, 6,6^{\prime}, 6^{\prime \prime}$-Octanitroterphenyl & $1.80^{\mathrm{c}}$ & $1.78(1.1)$ & $1.79(0.6)$ \\
\hline TPT & $\mathrm{C}_{21} \mathrm{H}_{6} \mathrm{~N}_{22} \mathrm{O}_{13}$ & 2,4,6-Tripicryl-s-triazine & $1.67^{c}$ & $1.80(-7.8)$ & $1.81(-8.4)$ \\
\hline DODECA & $\mathrm{C}_{24} \mathrm{H}_{6} \mathrm{~N}_{22} \mathrm{O}_{24}$ & Dodecanitro-quatraphenyl & $1.81^{\mathrm{c}}$ & $1.84(-1.7)$ & $1.85(-2.2)$ \\
\hline $\mathrm{ABH}$ & $\mathrm{C}_{24} \mathrm{H}_{2} \mathrm{~N}_{14} \mathrm{O}_{24}$ & Azo bis $\left(2,2^{\prime}, 4,4^{\prime}, 6,6^{\prime}-\right.$ hexanitrobipheny 1$)$ & $1.78^{\mathrm{c}}$ & $1.83(-2.8)$ & $1.84(-3.4)$ \\
\hline TPB & $\mathrm{C}_{24} \mathrm{H}_{8} \mathrm{~N}_{8} \mathrm{O}_{18}$ & 1,3,5-Tripicry lbenzene & $1.67^{\mathrm{c}}$ & $1.7(-4.2)$ & $1.74(-4.2)$ \\
\hline
\end{tabular}

${ }^{a}$ Ref. 37

${ }^{\text {bRef. } 39}$

${ }^{c}$ Ref. 40

${ }^{\mathrm{d}}$ Ref. 38 


\begin{tabular}{lccc}
\hline \hline \multirow{2}{*}{ TABLE IX. Calculated Densities for Some Proposed Explosives Compounds and Known } \\
Related Compounds.
\end{tabular}

"Using the linear and nonlinear least-squares S34 results 


\begin{tabular}{|c|c|c|c|c|c|c|c|c|c|}
\hline \multirow[b]{2}{*}{ Name } & \multirow{2}{*}{$\begin{array}{l}\text { Observed } \\
\text { Density } \\
\left(\mathrm{g} / \mathrm{cm}^{3}\right)\end{array}$} & \multirow[b]{2}{*}{$\mathrm{k}_{\max }$} & \multicolumn{4}{|c|}{ Calculated Density $\left(\mathrm{g} / \mathrm{cm}^{3}\right)$} & \multirow[b]{2}{*}{ a } & \multirow[b]{2}{*}{ c } & \multirow[b]{2}{*}{$\mathbf{c}^{\prime}$} \\
\hline & & & $\begin{array}{l}k=0 \\
\text { Linear }\end{array}$ & $\begin{array}{c}\mathbf{k}=\mathbf{0} \\
\text { Nonlinear }\end{array}$ & $\begin{array}{c}\mathbf{k}=\mathbf{k}_{\max } \\
\text { Linear }\end{array}$ & $\begin{array}{c}\mathbf{k}=\mathbf{k}_{\max } \\
\text { Nonlinear }\end{array}$ & & & \\
\hline $\begin{array}{l}\text { PROP } \\
\text { CUBANE } \\
\text { BCU } \\
\text { PCU } \\
\text { PRIS6 } \\
\text { TAM } \\
\text { ADAMAN } \\
\text { CONGRS } \\
\text { TRIAMT }\end{array}$ & $\begin{array}{l}1.33 \\
1.08 \\
1.21 \\
1.24\end{array}$ & $\begin{array}{r}12 \\
8 \\
10 \\
14 \\
12 \\
12 \\
16 \\
20 \\
24\end{array}$ & $\begin{array}{l}1.11 \\
1.37 \\
1.31 \\
1.23 \\
1.37 \\
1.31 \\
1.10 \\
1.17 \\
1.20\end{array}$ & $\begin{array}{l}1.10 \\
1.36 \\
1.30 \\
1.22 \\
1.36 \\
1.33 \\
1.10 \\
1.16 \\
1.19\end{array}$ & $\begin{array}{l}2.07 \\
2.11 \\
2.10 \\
2.09 \\
2.11 \\
2.11 \\
2.08 \\
2.09 \\
2.09\end{array}$ & $\begin{array}{l}2.08 \\
2.12 \\
2.12 \\
2.11 \\
2.12 \\
2.13 \\
2.09 \\
2.10 \\
2.10\end{array}$ & $\begin{array}{l}108 \\
104 \\
118 \\
146 \\
156 \\
140 \\
136 \\
188 \\
240\end{array}$ & $\begin{array}{r}97.19 \\
75.82 \\
90.08 \\
118.59 \\
113.73 \\
106.64 \\
123.45 \\
161.36 \\
200.40\end{array}$ & $\begin{array}{r}98.01 \\
76.26 \\
90.58 \\
119.24 \\
114.38 \\
105.35 \\
124.10 \\
162.23 \\
201.64\end{array}$ \\
\hline
\end{tabular}

Densities are given for the unsubstituted prisanes $(k=0)$ and the totally nitrated prisanes $\left(k=k_{\max }\right)$. 


\section{REFERENCES}

1. C. H. Johansson and P. A. Persson, Detonics of High Explosives (Academic Press, London, 1970), pp. 31-39.

2. W. Fickett and W. C. Davis, Detonation (University of California Press, Berkeley, 1979), pp. 24-35.

3. M. J. Kamlet and S. J. Jacobs, "Chemistry of Detonations. I. A Simple Method for Calculating Detonation Properties of C-H-N-O Explosives," J. Chem. Phys. 48, 23-35 (1968).

4. M. J. Kamlet and J. E. Abland, "Chemistry of Detonations. II. Buffered Equilibria," J. Chem. Phys. 48, 36-42 (1968).

5. M. J. Kamlet and C. Dickinson, "Chemistry of Detonations. III. Evaluation of the Simplified Calculational Method for Chapman-Jouguet Detonation Pressures on the Basis of Available Experimental Information," J. Chem. Phys. 48, 43-50 (1968).

6. M. J. Kamlet and H. Hurwitz, "Chemistry of Detonations. IV. Evaluation of a Simple Predictional Method for Detonation Velocities of C-H-N-O Explosives," J. Chem. Phys. 48, 3685-3692 (1968).

7. M. J. Kamlet and J. M. Short, "The Chemistry of Detonations. VI. A 'Rule for Gamma' as a Criterion for Choice Among Conflicting Detonation Pressure Measurements," Combustion and Flame 38, 221-230 (1980).

8. S. W. Benson and J. H. Buss, "Additivity Rules for the Estimation of Molecular Properties. Thermodynamic Properties," J. Chem. Phys. 29, 546-572 (1958).

9. L. R. Rothstein and R. Petersen, "Predicting High Explosive Detonation Velocities from their Composition and Structure," Propellants and Explosives 4, 56-60 (1979).

10. I. N. Aizenshtadt, "A Method of Calculating the Ideal Detonation Velocity of Condensed Explosives," Fizika Goreniya i Vzryva 12, 754-758 (1976), English translation, 675-678 (1976).
11. D. E. Williams, "Computer Calculation of Molecular Crystal Structures," Science 159, 645-646 (1968).

12. D. E. Williams, "A Method of Calculating Molecular Crystal Structures," Acta Cryst. A25, 464-470 (1969).

13. D. E. Williams, "Molecular Packing Analysis," Acta Cryst. A28, 629-635 (1972).

14. D. E. Williams and T. L. Starr, "Calculation of the Crystal Structures of Hydrocarbons by Molecular Packing Analysis," Computers and Chemistry 1, 173-177 (1977).

15. J. R. Partington, An Advanced Treatise on Physical Chemistry. Vol. II. The Properties of Liquids (Longmans, Green and Co., London, 1951), pp. 17-28.

16. J. R. Partington, An Advanced Treatise on Physical Chemistry. Vol. III. The Properties of Solids (Longmans, Green and Co., London, 1952), pp. 154-162.

17. O. Exner, "Additive Physical Properties. Vol. II. Molar Volume as an Additive Property," Collection Czech. Chem. Commun. 32, 1-22 (1967).

18. O. Exner, "Conception and Significance of the Parachor," Nature 196, 890-891 (1962).

19. A. T. Nielsen, "Calculation of Densities of Fuels and Explosives from Molar Volume Additive Increments," Naval Weapons Center report NWC TP 5452 (February 1973).

20. C. M. Tarver, C. L. Coon, and J. M. Guimont, "Density Estimation for New Solid and Liquid Explosives," Stanford Research Institute report PYU 5425 (February 1977).

21. C. M. Tarver, "Density Estimations for Explosives and Related Compounds Using the Group Additivity Approach," J. Chem. and Eng. Data 24, 136-145 (1979).

22. A. Immirizi and B. Perini, "Prediction of Density in Organic Crystals," Acta Cryst. A33, 216-218 (1977). 
23. D. A. Cichra, J. R. Holden, and C. Dickinson, "Estimation of 'Normal' Densities of Explosive Compounds from Empirical Atomic Volumes," Naval Surface Weapons Center report NSWC TR 79-273 (February 1980).

24. A. I. Kitaigorodsky, Molecular Crystals and Molecules (Academic Press, New York, 1973), pp. 18-21.

25. H. H. Cady, "Estimation of the Density of Organic Explosives from Their Structural Formulas," Los Alamos Scientific Laboratory report LA-7760-MS (August 1979).

26. A. Bondi, "van der Waals Volumes and Radii," J. Phys. Chem. 68, 441-451 (1964).

27. N. R. Draper and H. Smith, Applied Regression Analysis (John Wiley, New York, 1968).

28. G. L. Tietjen, R. H. Moore, and R. J. Beckman, "Testing for a Single Outlier in Simple Linear Regression," Technometrics 15, 717-721 (1973).

29. F. E. Grubbs, "Procedures for Detecting Outlying Observations in Samples," Technometrics 11, 1-21 (1969).

30. P. W. Holland and R. E. Welsch, "Robust Regression Using Iteratively Reweighted Least-Squares," Commun. Statis.-Theor. Meth. A6, 813-827 (1977).

31. P. J. Huber, "Robust Estimation of a Location Parameter," Ann. Math. Stat. 35, 73-101 (1964).

32. R. Fletcher and C. M. Reeves, "Function Minimization by Conjugate Gradients," Computer J. 7, 149-154 (1964).

33. F. H. Allen, S. Bellard, M. D. Brice, B. A. Cartwright, A. Doubleday, H. Higgs, T. Hum- melink, B. G. Hummelink-Peters, O. Kennard, W. D. S. Motherwell, J. R. Rodgers, and D. G. Watson, "The Cambridge Crystallographic Data Center: Computer-Based Search, Retrieval, Analysis and Display of Information," Acta Cryst. B35, 2331-2339 (1979).

34. O. Kennard, D. Watson, F. Allen, W. Motherwell, W. Town, and J. Rodgers, "Crystal Clear Data," Chem. Brit. 11, 213-216 (1975).

35. O. Kennard, F. H. Allen, M. D. Brice, T. W. A. Hummelink, W. D. S. Motherwell, J. R. Rodgers, and D. G. Watson, "Computer Based Systems for the Retrieval of Data: Crystallography," Pure and Appl. Chem. 49, 1807-1816 (1977).

36. F. H. Allen, O. Kennard, W. D. S. Motherwell, W. G. Town, D. G. Watson, T. J. Scott, and A. C. Larson, "The Cambridge Crystallographic Data Centre. Part 3. The Unique Molecule Program," J. Appl. Cryst. 7, 73-78 (1974).

37. R. Meyer, Explosives (Verlag Chemie, Weinheim, 1977).

38. Brigitta M. Dobratz, Compiler-Editor, "Properties of Chemical Explosives and Explosive Simulants," Lawrence Livermore Laboratory report, UCRL-39319 Rev. 1, 1974.

39. "Engineering Design Handbook, Explosives Series, Properties of Explosives of Military Interest," Army Materiel Command report AMCP-706-177 (January 1971).

40. C. L. Mader, Numerical Modeling of Detonations (Univ. of California Press, Berkeley, 1979).

41. W. P. Norris, NAVSEA Explosives Program Reviews, Asilomar, California, December 15-19, 1980. 